\title{
1 UK economic outlook: Brisk but not better growth
}

\author{
by Hande Küçük, Cyrille Lenoël and Rory Macqueen ${ }^{1}$
}

\section{Economic background and overview of the forecast}

\section{Recent developments}

\section{Getting on top of Covid-19 is key to UK recovery}

After a year in which the UK suffered one of the worst Covid-19 death rates in the world, coupled with one of the deepest recessions, there are now grounds for some optimism about recovery in both respects. A successful lockdown and vaccination programme this year have seen numbers of deaths and hospitalisations fall to levels last seen in September 2020. The R-number, according to the NIESR Covid tracker based on data until 4th May, is stable around $0.85-1.00$.

Adapting to lockdowns means that the economy is well-placed ahead of re-opening

Economic data, official and unofficial, have exceeded many expectations in the first few months of 2021. Despite the national lockdown that commenced in January, activity has not fallen to the same degree as in the first national lockdown, and high frequency indicators suggest strengthening throughout March and April (see Figure 1.2).

While the hospitality sector was smaller by over 50 per cent compared with a year earlier, and the arts by over a third, both manufacturing and construction output were only 4 per cent lower in February. Output in the public administration, health and energy sectors was higher than a year earlier.

\section{Labour market indicators suggest rapid hiring in spring}

Recent KPMG/REC job surveys show that we should expect further improvements in the labour market from March when lockdown restrictions began to be lifted. The April survey pointed to the fastest rise in permanent placements in over 23 years, while temporary hiring grew for the ninth month in a row.
High-frequency indicators also suggest return to preCovid levels

There has been a 'decoupling' of output from broad activity measures such as the Google Mobility data, shown in Figure 1.3. During the first lockdown, mobility data provided a useful indicator of the fall and recovery in GDP but, since January, the relationship has been less close. It is nonetheless possible to discern a return to something close to pre-pandemic mobility levels in April. Construction is one sector which was badly affected in Spring 2020 but which, as suggested by Figure 1.2, has been back to preCovid levels for some time.

Surveys have provided some evidence of resilience, especially towards the end of the first quarter, and April's IHS Markit Flash Composite PMI suggested the fastest private sector growth rate since late 2013 .

\section{Figure 1.1 UK daily Covid-19 statistics}

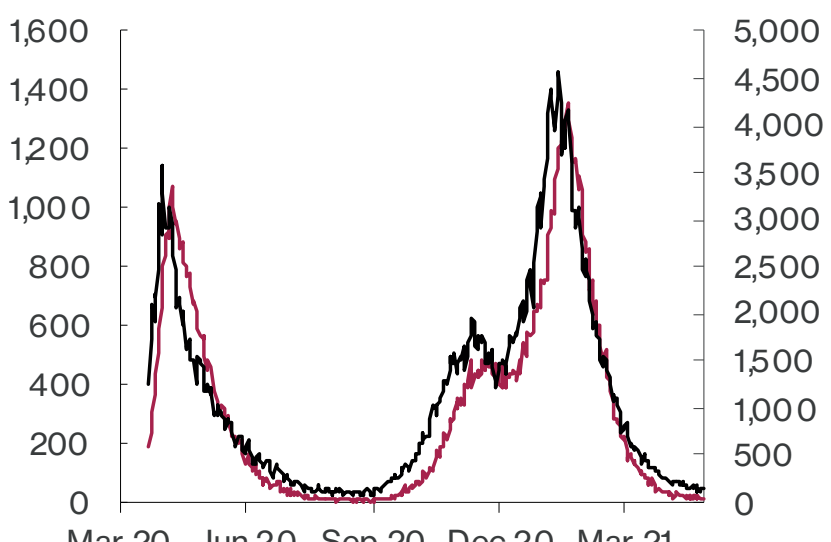

Mar 20 Jun 20 Sep 20 Dec 20 Mar 21

—Deaths within 28 days of a positive test (LHS)

— Patients admitted to hospital (RHS)

Source: Data.gov.uk. See coronavirus.data.gov.uk for further information.

1 We would like to thank Richard Barwell, Rhys Bidder, Jagjit Chadha, Iana Liadze, Barry Naisbitt, Adrian Pabst and Kemar Whyte for helpful comments and Patricia Sanchez Juanino for preparing the charts and the database underlying the forecast. The forecast was completed on 26 April 2021, more recent data are incorporated in the text. Unless otherwise specified, the source of all data reported in tables and figures is the NiGEM database and NIESR forecast baseline. All questions and comments related to the forecast and its underlying assumptions should be addressed to Cyrille Lenoël (c.lenoel@niesr.ac.uk). 


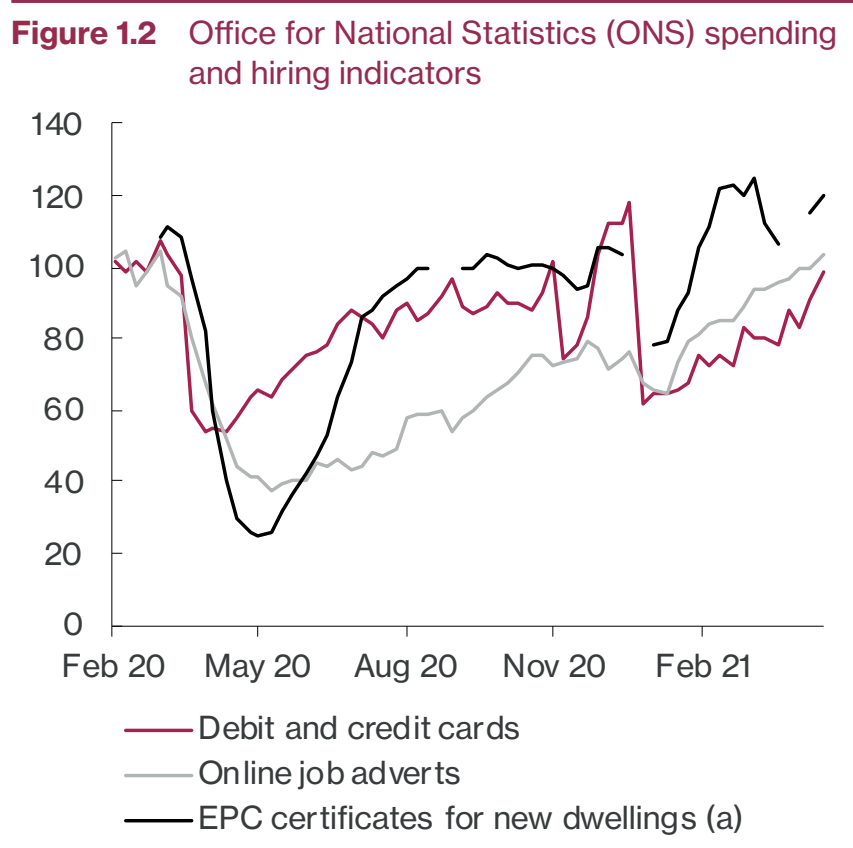

Notes: (a) England and Wales. Debit and credit cards (CHAPSbased): 100 = February 2020, percentage change on a backward looking seven-day rolling average, non-seasonally adjusted, nominal prices. Job adverts: change from the same week in 2019. EPC certificates: change from the same week in 2019/2020, four-week rolling average, adjusted for timing of holidays. Source: ONS, BoE, Adzuna, MHCLG, NIESR.

Figure 1.3 GDP and Google Mobility data

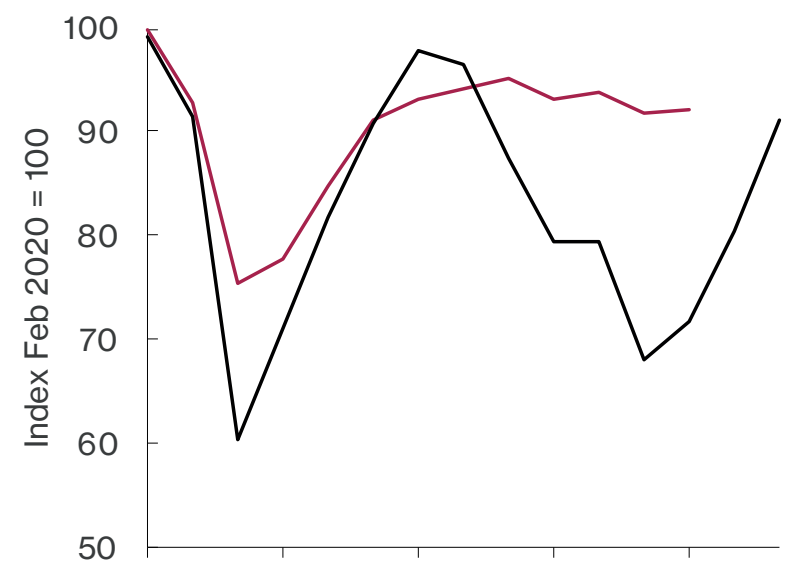

Feb 20 May 20 Aug 20 Nov 20 Feb 21

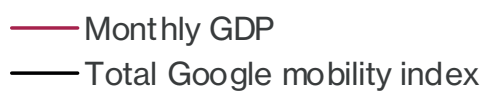

Source: Google, ONS, NIESR.

January disruption to trade has not fed through to wider economy

The Brexit transition period came to an end at almost the same time as the current lockdown was imposed. As a result, early data record the combined effects of short-term disruption, long-term supply chain reallocation, reduced demand under lockdown and Brexit-related stockbuilding in December. It may be some time before we can isolate the distinct effects of each of these (see Box A on page 18) but we have previously estimated the long-run impact on UK GDP of a Free Trade Agreement at around 31/2 per cent, of which about 2 per cent may have already taken place by year-end 2018 (Born et al, 2019).

These positive indications mean that our main case forecast scenario is conditioned on the lifting of remaining restrictions in line with the government's proposed timetable, ending domestic restrictions on 21 st June. A further resurgence of the virus constitutes a significant downside risk to all aspects of our forecast.

\section{The UK forecast}

Growth forecasts are revised up for $2021 \ldots$

Following the worst economic performance among G7 countries in 2020, optimism about the UK recovery is broad-based and well-founded. Our main case forecast scenario includes a significant upgrade to output growth in 2021 , from 3.4 per cent to 5.7 per cent, with growth of 4.5 per cent forecast for 2022 .

\section{...driven by unlocking sectors...}

Expectations for faster GDP growth prospects compared to our February forecast are driven by two major developments, both related to government policy. First, the lockdown imposed in January and one of the fastest vaccination programmes in the developed world have brought down new Covid-19 cases and deaths dramatically.

\section{...and public spending}

Secondly, the government has announced a large rise in Covid-related spending in the 2021-22 fiscal year. This spending contributes directly to GDP growth (see Figure 1.4) and the early confirmation of continuing support until September, in contrast with the last-minute U-turn over the Coronavirus Job Retention Scheme in October 2020, provides clarity and stability to households and businesses, allowing more confidence in forward planning. We project a lower forecast peak in the unemployment rate as a consequence.

Furlough is expected to limit the rise in job losses but unemployment will still rise

Our forecast is for unemployment to peak at 6.5 per cent at the end of 2021 (see Figure 1.12 on page 11), based on the announcements in the Budget. This represents a downward revision to our earlier forecasts in light of the extension of support.

\section{Inflation will rise but remain under control}

Despite upward revisions GDP will remain below preCovid levels until the end of next year and we do not anticipate a sustained rise in inflation, with Bank Rate on hold until 2023. Headline rises in CPI inflation, which reaches 1.8 per cent at the end of 2021, initially reflect low base effects from the early months of the pandemic. 
Figure 1.4 NIESR forecasts for growth in 2021

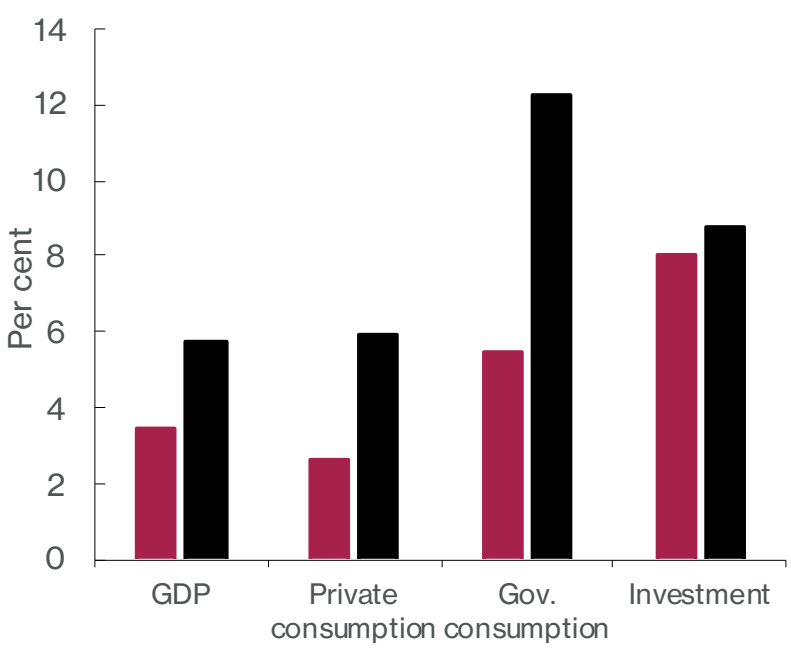

- February 2021 forecast

May 2021 forecast

Source: NIESR forecast.

Growth in total earnings is also forecast to accelerate, reaching 4.2 per cent in 2022 .

Businesses and consumers will both reduce their saving while government borrowing falls back to pre-Covid levels after three years

The recovery is expected to see domestic savings of households gradually fall and the corporate sector returns to net borrowing as business investment picks up. A progressive reduction in government borrowing is therefore the counterpart to the current account balance remaining roughly constant (see Figure 1.5). Government borrowing rises temporarily but is forecast to fall again thanks to a faster recovery.

But the pandemic is not over and nor is Covid-related uncertainty

Risks to our main case scenario remain elevated but appear to be approximately symmetrical. Households' incomes may be protected if the government announces further labour market support, or they may exhibit less caution in returning to lower rates of saving, with consequences for the recovery in consumer spending.

Equally the continued spread of the virus in other parts of the world policy and missteps both constitute major downside risks. The restraint shown by consumers after the lifting of restrictions in 2020 exemplifies the centrality of confidence in public health to the recovery of the economy.

\section{Economic activity}

A better-than-expected first quarter provides a solid foundation for the rest of the year

Following a slightly stronger finish to 2020, based on

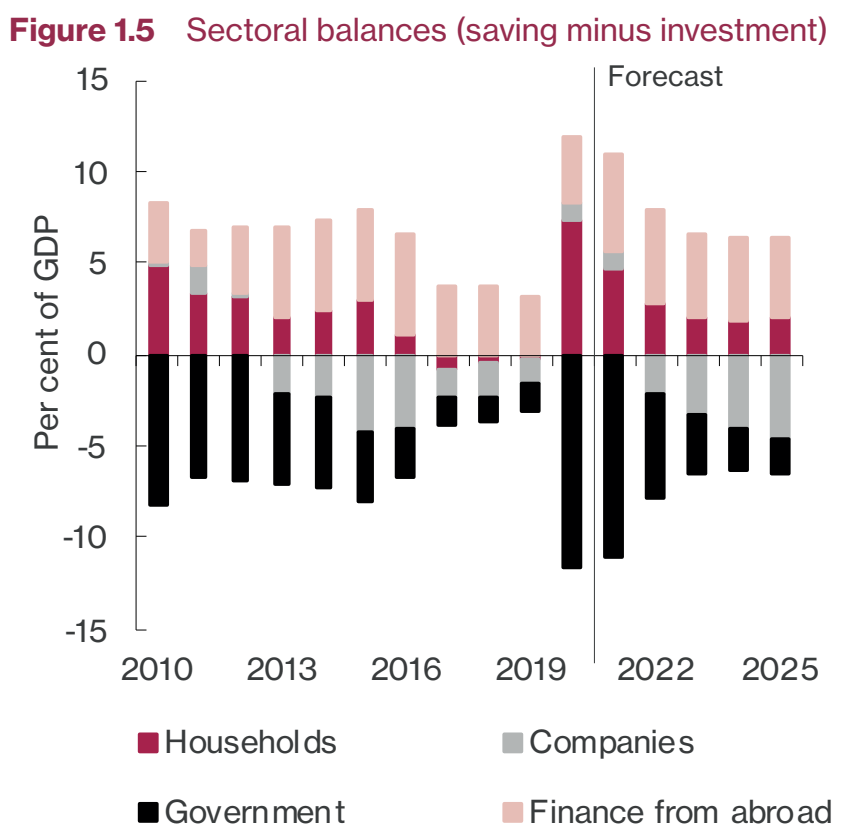

Source: NiGEM database and NIESR forecast.

surveys and high frequency indicators we anticipate a contraction of 1.6 per cent in the first quarter of the year (see Figure 1.6), which provides a stronger base for faster growth

GDP growth of 4.4 per cent in the second quarter is likely to be driven by the sectors most affected by continued restrictions: hospitality, retail, arts and recreation, followed by slower but still historically large growth in the third and fourth quarters.

This has consequences for subsequent growth, with GDP levels revised up throughout the forecast period Upward revisions to the forecast level of GDP continue through the year, supported by further spending announced at the Budget; the faster return to some kind of normal means that our main case forecast scenario for the level of GDP is around 3 per cent higher in 2025 than we forecast in February, returning to its pre-pandemic peak in the last quarter of 2022 (see Figure 1.7). Compared with our November 2019 forecasts this nonetheless constitutes a cumulative loss of around $£ 727$ billion (in 2018 prices) over the five-year period from 2020.

Significant uncertainty about household confidence and global control of the virus

An unusually high number of risks lie on both sides of our main case forecast scenario. The household sector's net worth grew by 9 per cent in 2020 and newly acquired savings may be spent more or less quickly than we anticipate (see page 14 and Chadha, 2017, for context). Further mutations of the Covid-19 virus, or developing resistance to vaccines, could mean that 21 st June is not the end of domestic restrictions. The worrying continued spread in other countries may have both public health and economic consequences for the UK, which remains an 
open economy relatively exposed to events overseas. The extent of these risks will be closely related to the lifting of travel restrictions in the $\mathrm{UK}$ and the vaccine roll-out in both the UK and the rest of the world.

Covid has not materially weakened or strengthened the long-term annual growth potential of the UK...

Looking further ahead, we continue to assume that Covid-19 has caused a downward shift to the level of UK output, but not to its growth rate in the long run. On the other hand, nor do we forecast permanent economic benefits, for example via a productive reallocation of capital. In conditioning on both of these assumptions, our main case forecast scenario does not envisage the experiences of 2020-21 having materially strengthened or weakened the long-run annual growth potential of the UK economy, which is around 1.5 per cent (see Fuentes and Moder, 2020, and Ilzetzki, 2021).

...but a poor Covid-19 response has had a permanent cost to the UK relative to other major economies

The size of the economic fall does, however, mean that the level of GDP is around 4 per cent lower in 2025 than we had forecast it to be before the Covid-19 pandemic, equivalent to around $£ 1,350$ per person per year (2018 prices). While all countries have seen downgrades in their economic outlooks, those which have handled Covid-19 well are likely to find their long-term growth prospects downgraded by less.

Figure 1.6 Projected quarterly growth in 2021

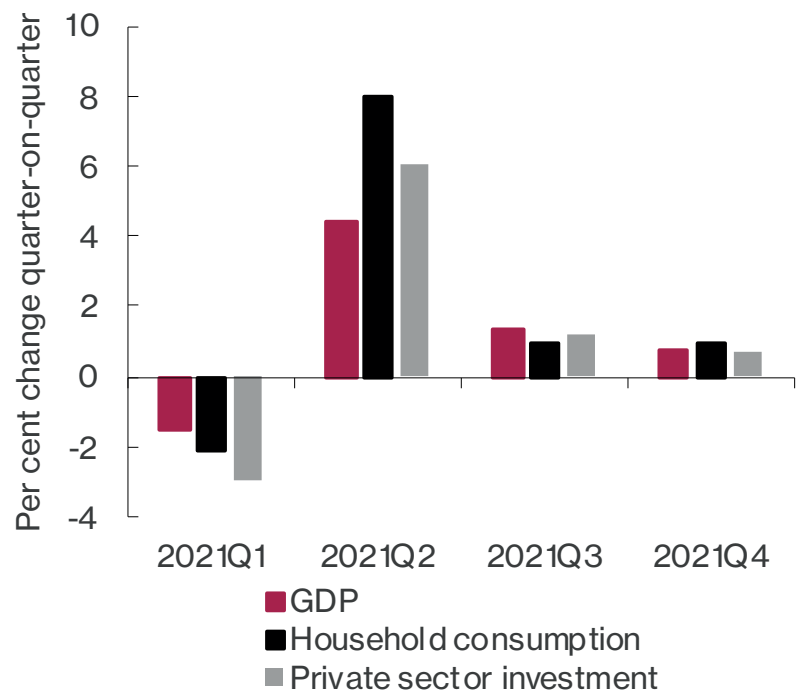

Note: Household consumption is household and NPISH final consumption expenditure (durable and non-durable). Source: NiGEM database and NIESR forecast.
The UK's 9.8 per cent fall in GDP last year was the largest in the G7 and, while some of this is accounted for by different measurement of public sector output and a larger output share for social consumption, the majority is attributable to the greater prevalence of the pandemic in the UK, something partially driven in turn by the UK's relatively unprepared health system (see page 25 ).

In our last forecast before the pandemic began we expected that GDP per capita would be 14 per cent lower in the UK than in the US and Germany in 2025. According to our current forecasts the differences will now be 19 per cent and 16 per cent respectively. Clearly this divergence (see Figure 1.9) relates both to the depths of the 2020 recessions and to the forecast strength of the forecast post-Covid recoveries. Both the immediate handling of any future pandemic and decisions about how to respond afterwards will have major long-lasting consequences for living standards.

\section{The post-pandemic economic landscape}

Long-term economic and social weaknesses have not disappeared...

Beyond short-term optimism the outlook for the UK economy is less certain. The challenges which faced the UK economy before the pandemic - low wages, low productivity, inequality and a reliance on consumer credit to drive expansion - look likely to characterise the recovery. In some cases there is a risk that, despite the

Figure 1.7 Quarterly GDP fan chart

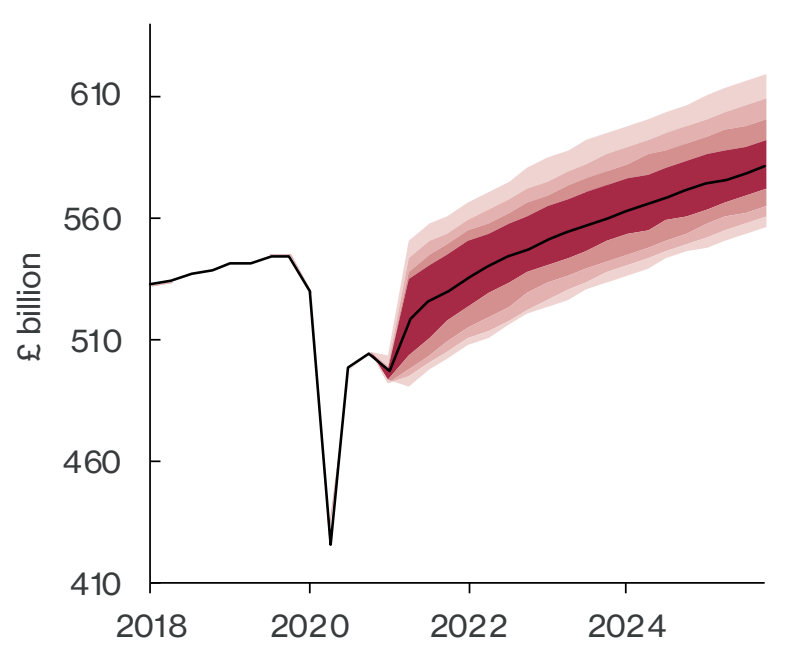

Note: The fan chart is intended to represent the uncertainty around the main-case forecast scenario shown by the black line. There is a 10 per cent chance that GDP growth in any particular year will lie within any given shaded area in the chart. There is a 20 per cent chance that GDP growth will lie outside the shaded area of the fan).

Source: NiGEM database, NiGEM forecast, NiGEM stochastic simulation and judgement. 
Figure 1.8 UK GDP pre-pandemic and latest forecasts

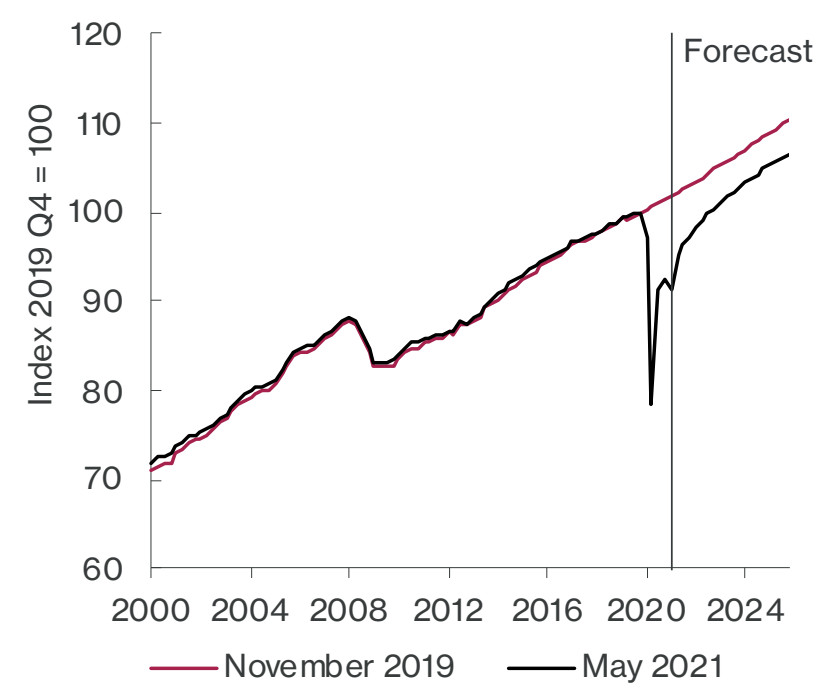

Source: NiGEM database and NIESR forecast.

rhetoric about 'building back better', existing inequalities could be cemented or exacerbated by Covid-19, and many of those who have in differing ways been at the forefront of the pandemic may now find themselves left behind by the recovery (see Hughson, 2021).

Young people who have missed out on education, and disproportionately contributed to rising unemployment figures so far, may have their employment and earnings prospects scarred (as we discussed in November ${ }^{2}$ ), while the continuing reliance on house price growth moves ownership further out of their reach. Businesses which have operated far below capacity over the past year are now those most likely to face hefty debts (see page 15). Many key workers who helped to deliver the government response to the pandemic will find their pay frozen while inflation rises and earnings elsewhere in the economy are forecast to grow healthily.

... and may have been made worse by the pandemic and uneven recovery

Without further policy intervention there are likely to be a substantial group of private sector workers, including many in retail, who have found, or will find as furlough ends, that their former jobs have disappeared, automated or moved online. There is likely to be dislocation, at least in the medium term, between the new jobs being created and those looking for work. The prospects for individual sectors are discussed in Chapter 2 and those for the regions and nations of the $\mathrm{UK}$ in Chapter 3.
Figure 1.9 Growth in GDP per capita (2019-2025) pre-pandemic and latest forecasts

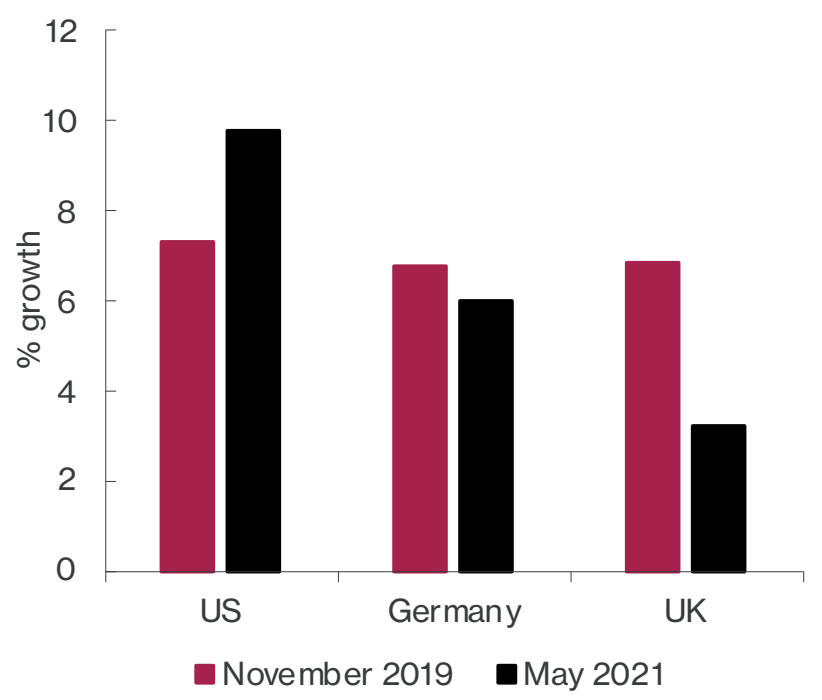

Source: NiGEM database and NIESR forecasts.

A change to our approach to fiscal policy has never been more urgent

This uneven impact of Covid-19 partly reflects both the nature of a virus which thrives on social interaction and an understandable desire on the part of policymakers to 'freeze' the economy in its pre-Covid form pending the conclusion of what was hoped to be a short-term shock. Now, should the worst be behind us, there has never been a more appropriate time to review both the differential impacts of those decisions and the fiscal policy framework we will need to adopt to support the recovery.

A new NIESR Occasional Paper (Chadha et al, 2021) focuses on various elements of the current fiscal settlement in the UK, including the fiscal response to the pandemic, and lays out new policy proposals which are discussed further on page 26 . One of the key issues with the current framework is the disconnect between the economic objective of fiscal policy, the social welfare function, and a concern with public debt as a share of national income. Fiscal rules have been frequently changed by governments and are sensitive to political rather than economic criteria, as they are tied to parliamentary timetables which do not really coincide with economic cycles, undermining their credibility. Hence, a robust fiscal framework should combine clear principles for spending and tax with statecontingent adjustments to support the ultimate objectives of fiscal policy - more robust and inclusive growth - with a medium-term perspective.

2 See Boshoff, J., Bowyer-Crane, C. and Stokes, L. (2020) 'Implications of school re-openings in the UK', NIER 254, F23 


\section{Households}

Household consumption to drive strong recovery After a first quarter of 2021 in which consumption held up better than expected there are widespread expectations for a consumer-led boom in the second quarter. Underlying these hopes lies an unprecedented degree of household savings which have accumulated during the pandemic, largely as a result of reduced opportunities for spending.

Household incomes were relatively well insulated in aggregate during 2020, though less so than in some countries. Employment figures have repeatedly outperformed expectations, largely due to repeated extensions to fiscal support in the form of the Coronavirus Job Retention Scheme (CJRS) and Self-employment Income Support Scheme, which are now forecast by the Office for Budget Responsibility (OBR) to take virusrelated income support to slightly over $£ 100$ billion in total. A further extension of support to September was announced in March, with CJRS employer contributions being phased in from July.

\section{Labour market}

Unemployment has risen only modestly and has been concentrated among certain sectors and groups

The official unemployment measure fell to 4.9 per cent in December-February, though there were over 4 million people still on the furlough scheme at the end of March, according to provisional data (see Figure 1.10). Compared with a year earlier, employment according to the Labour Force Survey was 640,000 lower, with 310,000 of that accounted for by the rise in unemployment and 331,000 more economically inactive.

Both of these changes have been concentrated among young people. According to the Institute of Employment Studies, PAYE employment for the young has fallen by 12 per cent since the start of the pandemic, compared with 1.4 per cent for other age groups, and has recently begun falling while it rises for others.

\section{While the furlough scheme initially protected against job destruction... \\ To the surprise of most analysts, the economy has created more jobs than it lost during the winter lockdown. For the first time since the beginning of the pandemic, the number of people in employment in the UK expanded in February 2021, bringing the employment rate to 75.0 per cent, having steadily declined from 76.7 pre-Covid to 74.9 per cent. Labour market policies have once again proved effective at limiting the rise in unemployment that would have been expected from a contraction of GDP by 1.6 per cent in the three months to February.}

... and continues to do so for around one-in-seven workers...

We forecast the number of furloughed workers to decline steadily from the end of March until September when
Figure 1.10 Numbers and estimates of workers furloughed on Coronavirus Job Retention Scheme

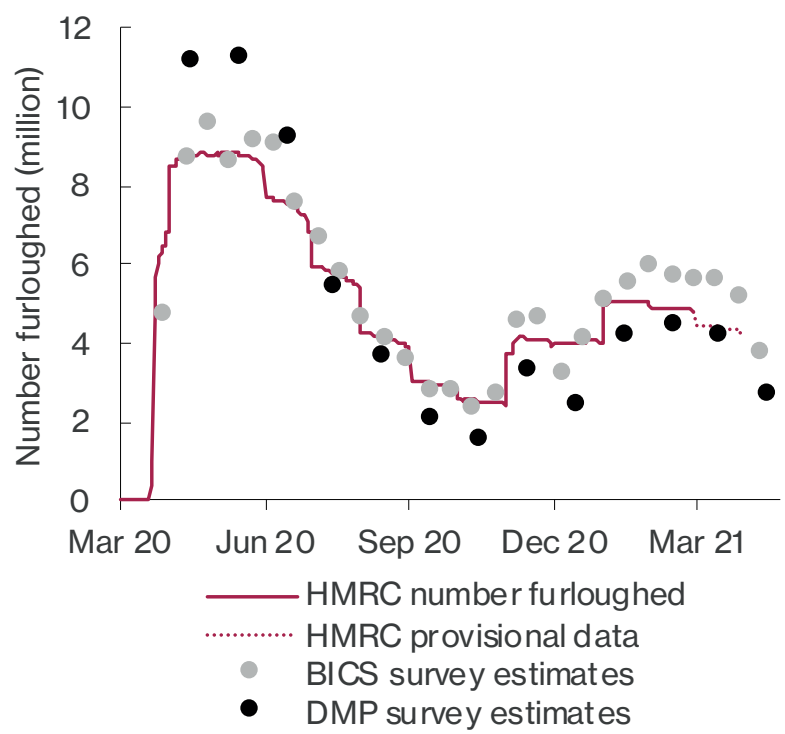

Source: Source: NIESR, HMRC, ONS Business Impact of Coronavirus Survey, Bank of England Decision Maker Panel survey. Survey estimates are not strictly comparable: see ONS 'Comparison of furloughed jobs data, UK: March 2020 to January 2021', 5 March.

the furlough scheme is planned to end. But the improved optimism that the worst of the pandemic may be over should be tempered by the fact if employers are waiting until the end of lockdown to reassess business plans.

Redundancies continued to decline from a peak of 14.6 per thousand in the three months to November 2020 to 7.3 per thousand in the three months to February 2021. We expect the rate of redundancies to continue to decline in the next few months given that the number of planned redundancies declined in February to a level lower than a year ago before the pandemic hit.

...job creation is now playing its part in keeping unemployment down

Figure 1.11 shows the Beveridge Curve for the UK over the past twenty years and indicates how the CJRS has led to a breakdown in the relationship between unemployment and vacancies (see Macqueen, 2020b). 600,000 vacancies, as in December 2020-February 2021, was associated with a headline unemployment rate of around 7 per cent during the recovery after the Global Financial Crisis.

ONS estimates indicate a 16 per cent rise in vacancies in March compared with February, though this remained 18 per cent below the pre-Covid level. Latest data from Adzuna (see Figure 1.2 on page 6 ) suggest that hiring may have picked up further since then, with online vacancies on 16 April at 99 per cent of their February 2020 level. Some of this is likely to represent switching from offline 
Figure 1.11 The UK Beveridge Curve 2001-2021

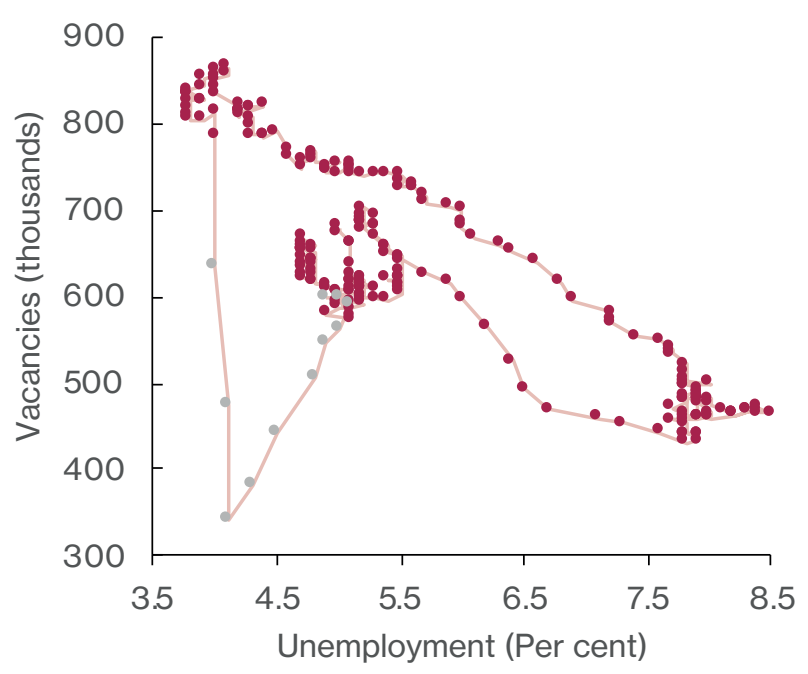

Note: Grey dots represent observations during the Coronavirus Job Retention Scheme's operation.

Source: ONS, NIESR calculations.

advertising and a pent-up demand for hiring which will ease after the second quarter of the year.

Active labour market policies will be required to prevent a rise in unemployment later this year and smooth any Covid-driven sectoral reallocation

While protecting jobs was clearly and understandably the government's first priority, sustained job creation will be required to ensure that the end of fiscal support does not lead to a major rise in the unemployment rate given postCovid labour market transitions due to a larger ecommerce sector, permanent remote working arrangements, more automation, increased emphasis on health, social care and education (Pissarides, 2020).

\section{Unemployment is still expected to rise when furlough ends}

Our forecast path for unemployment, which remains at 6.5 per cent into the first quarter of 2022, is compatible with an assumption that around 450,000 of those remaining on furlough in September will not be taken back after the scheme ends (see Figure 1.12).

\section{Earnings growth slowed last year...}

After falling in the first half of 2020, median monthly pay for payrolled employees increased sharply in the second half of 2020 and reached 5.4 per cent in March 2021 (HMRC's PAYE RTI database). Starting salaries rose in March for the first time in 2021 as temporary wages increased for the first time in three months.

...but is now firm, and not just due to compositional effects

Monthly pay growth data can mislead as it does not take into account any changes in the composition of the labour force. Looking at the distribution of pay growth between
Figure 1.12 UK unemployment

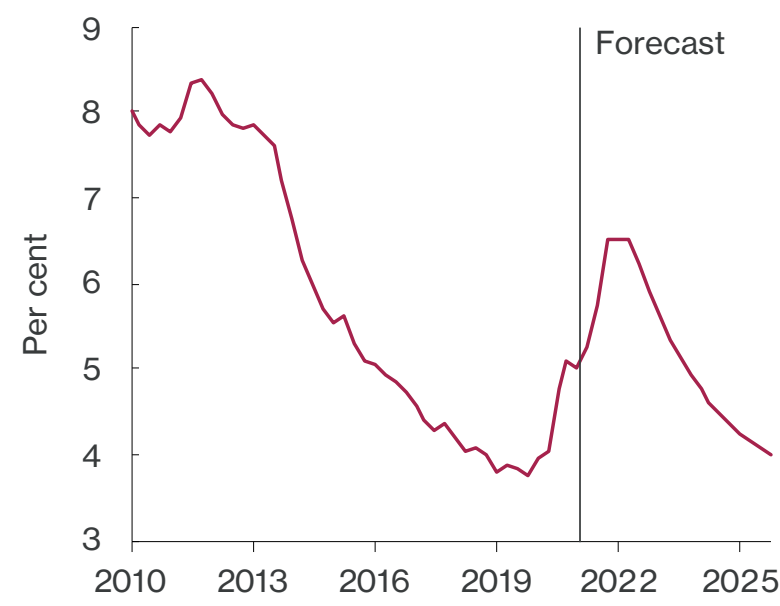

Source: ONS, NIESR forecast.

February 2020 and February 2021, when median pay growth was 4.5 per cent, Figure 1.13 shows that wage growth was apparently highest for the lowest earners, with the top percentile also enjoying strong wage growth. This apparently sharp rise for lower-paid workers arises from a shift in pay distribution, with a higher proportion of lowearners losing their jobs. Removing compositional effects, the ONS estimates that underlying earnings growth is around $2 \frac{1}{2}$ per cent for the economy as a whole, while the headline measure for average earnings growth is $4 \frac{1}{2}$ per cent.

The KPMG/REC UK Report on Jobs indicates that an increase in demand for labour led to improvements in pay trends for March and April. Starting salaries rose for the first time in 2021, as temporary wages increased for the first time in three months. HMRC's PAYE RTI data of payrolled employees suggests that median monthly pay increased at a rate of 5.4 per cent in March.

We forecast earnings to strengthen this year and further next year, cementing a solid rise in household incomes When the economy recovers from the pandemic, we expect earnings growth to accelerate to 2.2 per cent in 2021 and 4.2 per cent in 2022 (Figure 1.14), a similar rate as seen in 2019 .

The proportion of employed people who worked from home increased in 2020 by 9.4 percentage points compared with 2019, with homeworking particularly widespread among the highest paid, the better qualified, the higher skilled and those living in London and the South East. The productivity effects of working from home and their reflections on the wage distribution will be important to monitor. Recent analysis by the ONS suggests that, prior to the pandemic, employees working mainly from home 
Figure 1.13 Pay growth at different percentiles of the income distribution

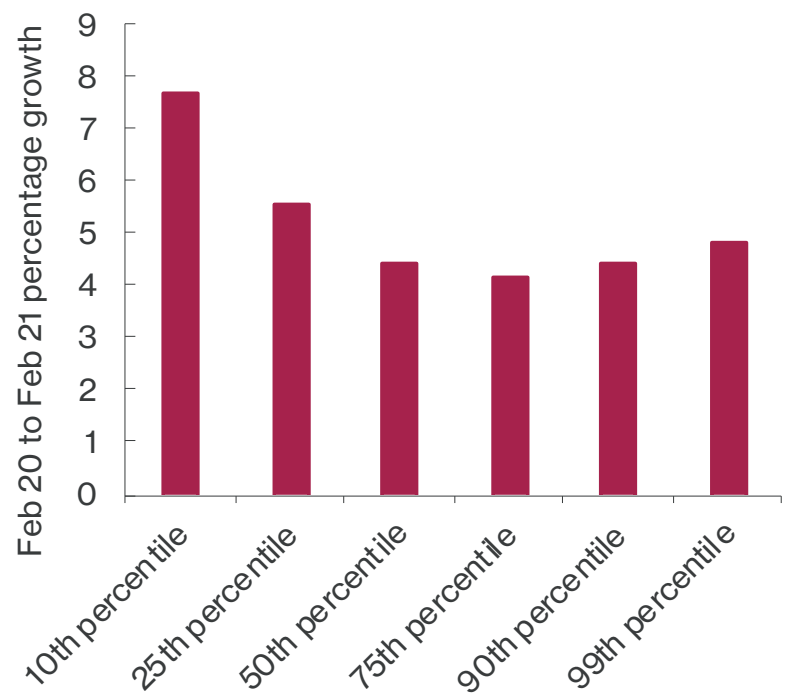

Source: HMRC.

had a lower salary, lower bonuses and were less likely to be promoted, after controlling for relevant factors, but that this negative relationship is not true for employees working occasionally from home.

\section{Housing market}

House price growth continues to outpace general price inflation, assisted by government policy

The housing market, an important component of household balance sheets, continues to outperform many other sectors. Property transactions in March were the highest level since comparable records began in 2005 and house prices rose by 8.6 per cent on a year earlier. According to Nationwide, strong growth continued with a month-on-month rise of 2.1 per cent in April. These data are likely to reflect the impact of the stamp duty holiday, which has been extended until the autumn (except in Scotland).

House prices are forecast to rise by 4 per cent in 2021 , building on strong growth last year, though this is expected to slow in years to come.

\section{Consumption and savings}

Greater optimism about household consumption than in our February forecast...

Looking ahead our forecast for household consumption is for growth of 8 per cent in the second quarter of the year and 5.9 per cent in 2021 overall (see Figure 1.15).

Partly this comes from a slightly faster fall in the savings rate, which is forecast to fall to 13.1 per cent this year and 10.7 per cent in 2022 , compared with 15.2 per cent then 11.0 per cent in our February forecast.
Figure 1.14 Growth rate of average earnings

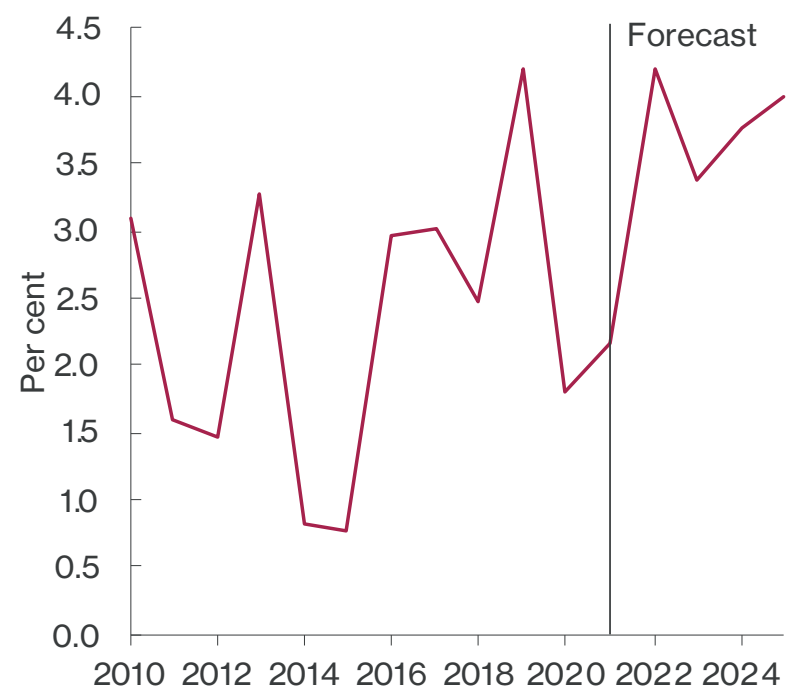

Source: ONS, NIESR forecast.

...reflects greater optimism about household incomes Predominantly, however, our better expectations for consumption are driven by better prospects for disposable incomes, which are forecast to rise by 3.1 per cent in real terms in 2021 and 2.7 per cent in 2022.

In the absence of any dramatic revisions to wealth forecasts, 2.4 of the 3.2 percentage point upgrade to our 2021 consumption forecast since February can be attributed to stronger income forecasts, with the remainder attributable to a lower rate of saving.

After last year's peak, household saving rates return to settle at a higher level than in 2016-2019...

There are clearly significant upside and downside risks to our main case forecast scenario path for consumption. The savings rate rose during the Global Financial Crisis (GFC) from an average of 8.2 per cent in the period 19972008 to 11.4 per cent in 2009 and reached a peak of 11.9 per cent in 2010. It then did not return to below its preGFC average of 8.2 per cent until 2016. In our main case scenario (see Figure 1.16), savings return to a level at the high end of the 1997-2008 range after reaching a much higher peak of 16 per cent in 2020, possibly reflecting a combination of precautionary motives, expectations of higher taxes in the future and 'consumption scarring' (Malmendier and Shen, 2019).

...which conceals diverging outcomes for households across the income distribution

A potential drag on spending comes from the fact that our aggregate forecasts for consumption and income are likely to conceal very different experiences, especially when differentiated by household income bracket. Furlough has been concentrated in low-wage sectors and so the same is likely to be true for the rise in unemployment which we 
Figure 1.15 Income and consumption of households

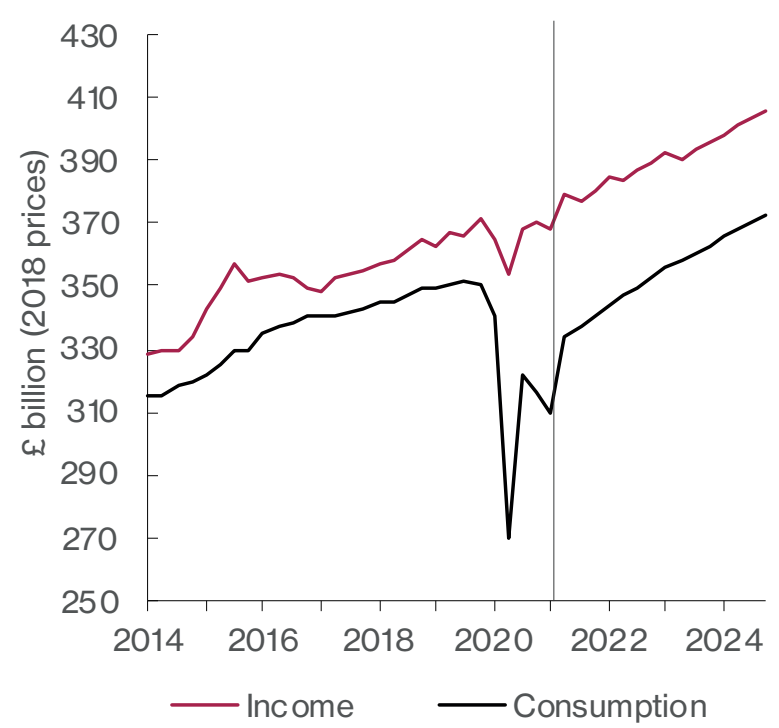

Note: Household consumption is household and NPISH final consumption expenditure (durable and non-durable).

Source: ONS, NIESR forecast.

forecast to follow the end of the CJRS. This in turn may act as a drag on wage growth in those sectors. This year and next may see a rise in poverty and destitution juxtaposed with healthily growing income and outgoings for households financially untouched by Covid-19: a further example of a recovery that differs across regions and the income distribution. In this case above-average income growth would be enjoyed by higher-earning deciles, who are generally believed to have a lower propensity to spend.

\section{Risks to main case consumption and savings path}

Households may not be as cautious as we expect, which constitutes an upside risk to consumption and GDP

One upside risk is that previous experiences may not be repeated after the Covid-19 savings glut, which was largely driven by reduced opportunities to spend: aggregate income did not rise. One recent study by the Federal Reserve Bank of Cleveland (Knotek et al, 2021) found that households' intentions to spend money on face-toface services after the pandemic has varied over the past year but that the typical consumer now expects to return to their previous level of spending on restaurants, bars, hotels and public transport.

Lockdowns have led to a large increase in household savings

However, the restrictions imposed on consumption over the past year mean that, not only have UK households amassed significant savings, but that the degree to which these savings will be subsequently run down is highly uncertain.
Figure 1.16 Gross savings ratio 2005-2030

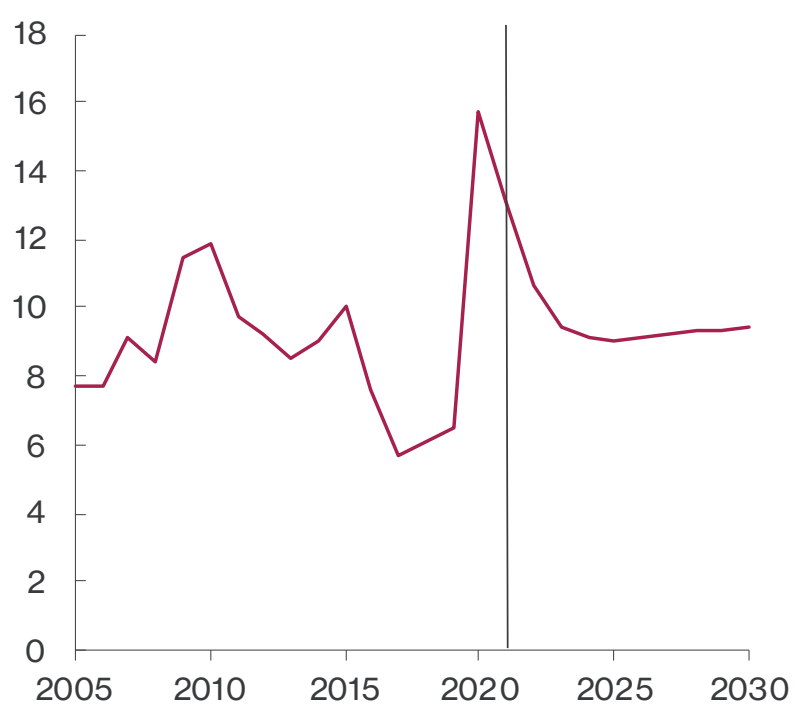

Source: NiGEM database and NIESR forecast.

As seen in Figure 1.5 on page 7 , these savings are the counterpart to government borrowing. Ricardian equivalence implies that a transfer from the government to households does not constitute an increase in their net wealth: they expect higher taxation in future and so save the windfall to pay this taxation.

These have largely been amassed by wealthier households, who saw consumption opportunities reduced

Strict Ricardian equivalence is rarely observed to hold, with some of all transfers always spent, but the windfall has clearly not been distributed evenly: higher-income households, who have a lower-than-average propensity to consume, saw their finances improve (see, for example, Bank of England, 2021b) far more than low-income households.

If taken at face value, the finding in the Bank of England February Monetary Policy Report that only 10 per cent of the households who increased their savings during the pandemic plan to spend at least part of them would strengthen the belief that the path of consumption is likely to be relatively unaffected by the build-up of savings. The degree of pent-up demand, while likely to support spending on delayable goods, will be constrained by natural limits to the number of haircuts and restaurant visits people can consume.

But they may be spent more quickly than wealth increases acquired from a conscious decision to save more

There are reasons to believe that the proportion of savings spent could be higher. Research around the Covid-19 stimulus cheques issued by the US government last year 
- also windfall income for many - suggested that around one-third was spent, one-third used to pay down debt and one-third saved. Recent research has also suggested the existence of a 'wealth hand-to-mouth' cohort, whose wealth is illiquid and who consume most of their transitory income increases. Kaplan et al (2014) find that this group constitutes over 20 per cent of households in the UK, suggesting that wealthier households with new savings may be more likely to spend them.

Around $£ 160$ billion has been added to household balance sheets, with most of that left in bank accounts We anticipate some running down of savings over the coming year when Covid-19 restrictions are expected to have been lifted. Extrapolation of pre-Covid average growth rates for income and consumption between 2012 and 2019 suggests that in our main case forecast scenario additional savings may have totalled around $£ 160$ billion over the period April 2020 - March 2021, compared with a no-Covid counterfactual. ${ }^{3}$ This is likely to be a conservative estimate as spending opportunities remained limited in the second quarter of this year.

To illustrate those two alternative scenarios, we run three simulations where the household savings rate (1) stays at the high level of the first quarter of 2021 ( 16 per cent) in the next three years, (2a) drops to its pre-Covid level of 6 per cent immediately, or (2b) temporarily drops to around 3 per cent to entertain the possibility that households may run down their accumulated savings in addition to reducing their savings to current income. In 2020, bank deposits owned by households increased by $£ 145$ billion, equivalent to 6.9 per cent of GDP. We therefore assume in this scenario that households spend all of the extra savings over the next three years.

Faster or slower falls in saving rates could translate into GDP being as much as 4 per cent lower or 3 per cent higher than forecast in Q4

The impacts on GDP of those three scenarios, simulated by NiGEM, are shown in Figure 1.17. In the downside scenario of higher savings GDP barely recovers from its level at the start of 2021 and would be around 4 per cent lower than the baseline after a year. In the scenario of lower savings, consumption quickly returns to its preCovid levels, but the increase in economic activity is more modest. GDP is 2.8 per cent higher in the first quarter, when the savings rate returns to 6 per cent, and 2 per cent higher in the fourth quarter. In the third scenario, where households also run down their accumulated savings, consumption increases quickly beyond the pre-Covid level; GDP is 3.9 per cent higher in the first quarter, 2.9 per cent in the fourth quarter, and would still be 1 per cent higher than baseline after three years.
Figure 1.17 GDP under alternative paths for household savings rates

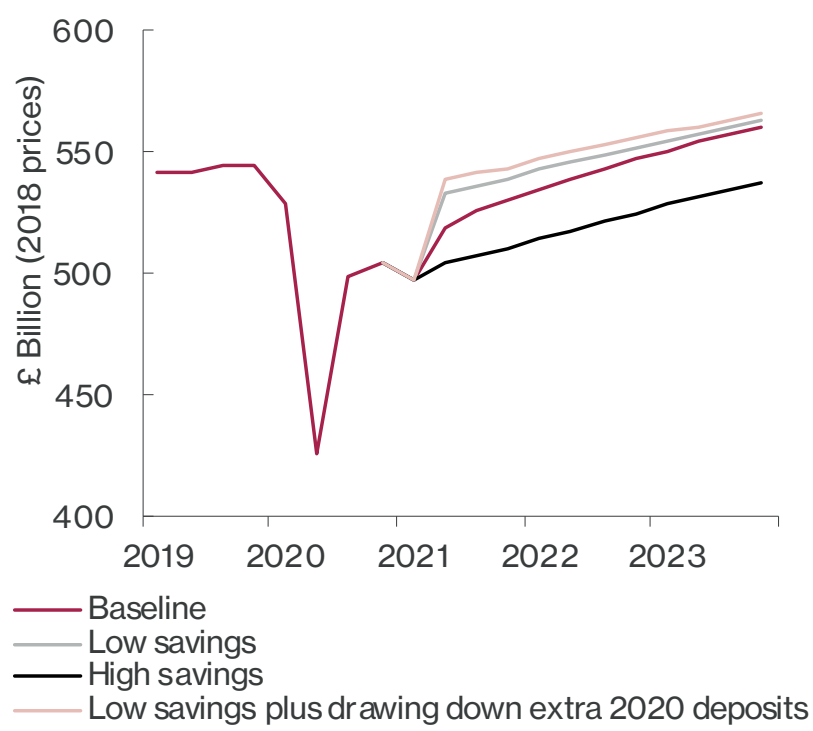

Source: NiGEM.

\section{Firms}

Demand conditions are very supportive for business, especially for sectors exiting lockdown

Early indications are that the lifting of Covid-19 restrictions on the hospitality and retail sectors have contributed to rapid growth in those sectors during March and April. According to the ONS, the reopening of non-essential retail stores on 12 April saw a weekly rise in 'delayable spending' on credit and debit cards from 63 to 89 per cent of February 2020 levels, while data from Springboard suggest that retail parks led the footfall recovery, at 102 per cent of the corresponding 2019 level in the week to 24 April.

Surveys of business owners indicate a strong degree of optimism, especially in terms of demand for their goods and services. The British Chambers of Commerce's Quarterly Economic Survey, concentrated on small and medium-sized enterprises, suggested that the number of firms reporting decreased cashflow actually fell slightly in the first quarter of the year, while expectations for turnover growth returned to pre-pandemic levels. Deloitte's survey of chief financial officers reported optimism at a record high, anticipating a strong recovery in profits and the strongest hiring and investment intentions in nearly six years.

3 Bank of England (2021b) estimated the extra savings accumulated as a result at $£ 125$ billion between March and November 2020, while Morgan Stanley suggested it may be of the order of $£ 170$ billion up to the end of the first quarter of this year. 
But a significant minority of firms has been devastated by the pandemic and may only continue under a weight of debt

While the CBI's industrial trends survey suggested manufacturing business sentiment grew at its quickest pace since April 1973 in recent months, corporate restructuring specialists Begbies Traynor reported a 15 per cent increase in businesses facing 'significant financial distress' ${ }^{4}$ This may reflect simply a backlog of firms which would normally have ceased to exist but have not done so due to government restrictions on winding-up petitions, and which are likely to when restrictions are lifted. But equally a large proportion of the corporate sector has taken on debt which it may be onerous to repay, even at generous interest rates, constituting a potentially longlasting shock to debt service payments and thus overall costs.

Financial conditions remain supportive but reflect different outlooks for different sized firms and across sectors Corporate lending has also showed signs of divergence. The Bank of England's credit conditions survey reported that spreads on corporate lending to SMEs widened while those for large firms narrowed, with the same pattern expected to consolidate.

UK stocks also imply divergence in recovery prospects UK stocks have underperformed other international indices since Brexit but equity prices have been affected in different ways by the pandemic: basic materials companies' stocks are up by a third since the start of last year while energy companies are down by a third (see Figure 1.18).

Diverging stock market fortunes may reflect a further divergence in expected fortunes in the post-Covid era between those firms which had to take on new debt to survive and those which have ridden out the pandemic largely unscathed, perhaps even seeing a rise in demand for certain goods and services while taking advantage of government cheap finance schemes. Overall, the nonfinancial corporate sector's debt-to-GDP ratio, which stood at 72.2 per cent by the end of 2019 , rose to 78.9 per cent by the end of 2020, according to the Institute for International Finance's Global Debt Database.

\section{Supply issues may rise but with uncertain pass-through to inflation}

The CBI survey also reported a rise in input costs linked to Covid-related supply chain disruption; Jaguar Land Rover reported halting production at two plants in late April due to chip shortages. These supply-side issues follow a rise in unit costs during Covid which the Bank of England estimates helped to offset the effect on inflation of falling demand on prices (Bank of England, 2021b). The extent to which future cost rises will feed through to inflation will depend on firms' pricing power in affected sectors.

\section{Figure 1.18 FTSE all-share price index}

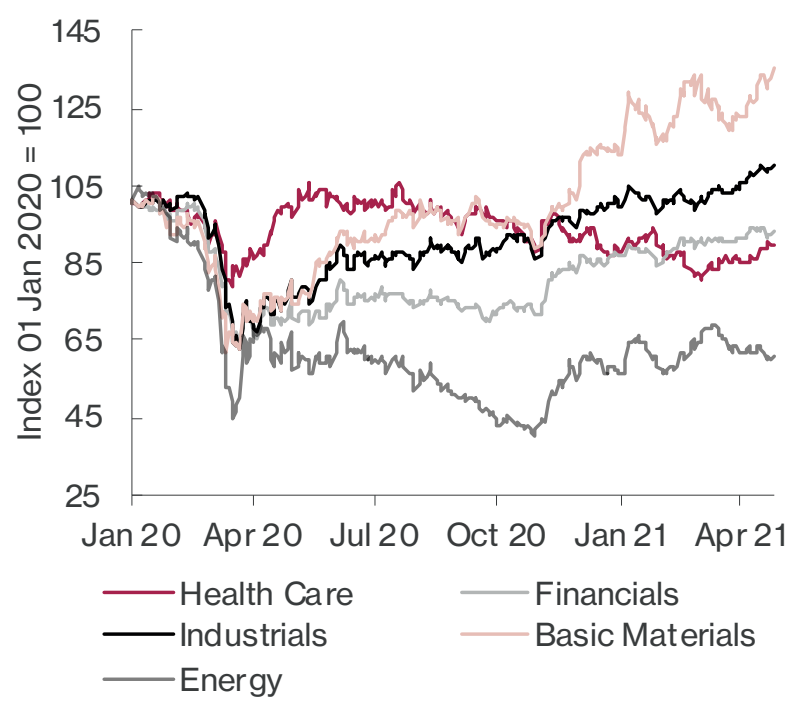

Source: Datastream.

Capital reallocation has been taking place since the start of the pandemic

Box D in Chapter 2 describes a sharp post-lockdown rise in company registrations for online retailers, food and drink providers, sports equipment production and pet care businesses. This may suggest the green shoots of a new business sector dynamism, but may also more prosaically reflect a reallocation of capital between types of firm with as yet indeterminate consequences for productivity.

\section{Investment and capital stock}

Tax policy acts to smooth investment in the short term and reduce it in long term

In March the government announced a rise in the main rate of corporation tax in 2023, from 19 per cent to 25 per cent, and a corporation tax 'superdeduction', which allows firms to offset 130 per cent of the cost of capital expenditure on plant and machinery without limit until then. The latter appears to be designed to reduce the incentive to delay investment which would otherwise arise: this investment can normally be 'written off' at 100 per cent up to an annual limit of $£ 1$ million, meaning a greater potential tax reduction after the corporation tax rise (see Smith, 2021).

The OBR estimates that the superdeduction will reduce corporate tax revenue by around $£ 12$ billion a year. We use this estimate to calibrate a reduction in effective corporate tax rate in the next two years. As a result firms bring forward investments, which accelerates the recovery in GDP. In the long run, the level of investment is lower than if corporate taxes were not increased in 2023 as planned.

4 'Red Flag alert Q1 2021', Begbies Traynor, 22 April 
Figure 1.19 Forecast 2021 growth of investment components

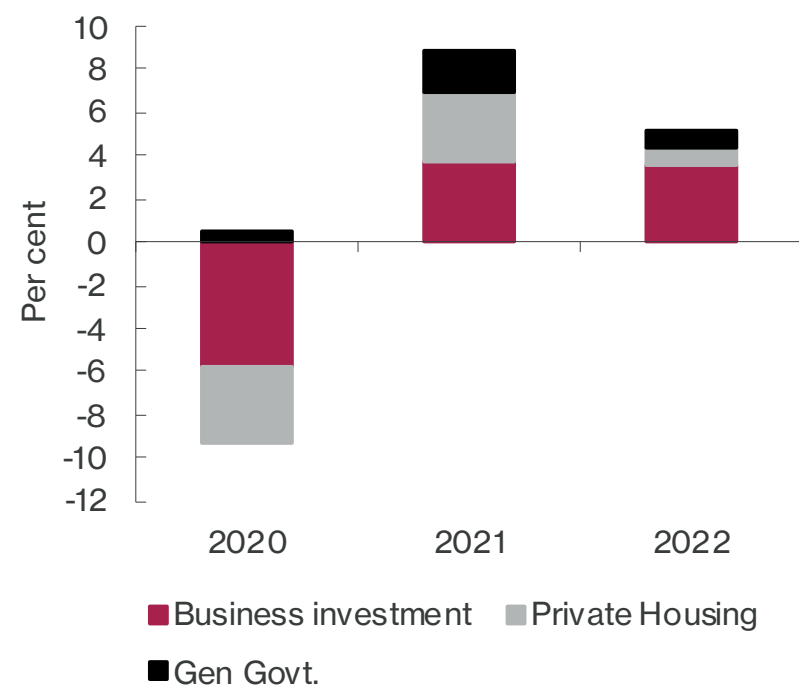

Source: ONS, NIESR forecast.

We noted in our February forecast and Budget response, supported by NiGEM analysis, that rises in sales or income taxes would have had smaller negative multiplier effects on the economy than rises in corporation tax.

But a faster recovery means more investment generally We forecast business investment to grow by 6.6 per cent this year and by 6.7 per cent in 2022: higher in level terms than our February forecast though apparently slower growth due to a smaller fall in 2020 than expected (see Figure 1.19).

In our main case forecast scenario private housing investment grows by 13 per cent in 2021 after falling 13 per cent in 2020. Total investment rises by nearly 9 per cent.

Over the course of the forecast period the private sector capital stock is forecast to grow by slightly over 1 per cent per year, reflecting weak pre-Covid trends and the effects of Brexit.

\section{Productivity}

Productivity increased in 2020 as low-productivity sectors disproportionately reduced their output

Despite the economic fallout from the pandemic, labour productivity measured as output per hour increased by 0.4 per cent in 2020 , as the fall in GDP was slightly larger than the drop in hours worked. As a result, annual productivity growth came close to its post-GFC average (Office for National Statistics, 2021), despite substantial quarterly volatility, due to the lockdowns and furlough scheme. Productivity rose by 6.5 per cent in the third quarter of 2020 and declined by 4.3 per cent in the fourth quarter, as output recovery stalled and hours increased faster especially in sectors such as manufacturing and construction.

Rising unemployment during economic recovery leads to above-average productivity rises in the medium term

The quarterly volatility in labour productivity is expected to persist in the first half of 2021 as the economy displays a strong rebound in the second quarter. As lockdown restrictions are phased out and consumer-facing services industries resume their activities, low-productivity industries will increase their share in employment and hours worked and the reallocation effect, which has supported productivity in 2020 , will be partially reversed in 2021 (Van Ark, 2021). We forecast output per hour to increase by 0.7 per cent in 2021, as we expect the recovery in output to be stronger than that in hours worked. While pent-up demand will lead to a strong recovery in consumption the adjustment in the labour market is likely to be slower due to post-pandemic transitions that will see unemployment rise.

In our main-case scenario, we forecast a higher rate of labour productivity growth from 2022, averaging 0.9 per cent a year for the period between 2022 and 2025, mainly driven by the economic recovery feeding through into higher growth in business investment (Figure 1.20). Despite this path, the level of productivity is still expected to be 2.6 per cent lower in 2025 than in our pre-Covid forecast; approximately two percentage points of this can be attributed to the change in assumption from a soft Brexit to an FTA and the remainder due to long-term scarring from Covid-19.

Long-term productivity shifts resulting from the pandemic remain largely uncertain

There are both upside and downside risks to our main case forecasts for productivity. Many firms have adjusted to the pandemic by accelerating their use of new technologies, including digitisation and automation, which might imply higher post-Covid productivity growth.

However, if productivity gains are concentrated in already high-performing businesses and are not reinvested to create employment and wage growth, economy-wide gains could be limited and short-lived. The recovery in business investment might also be weaker than expected if weak pre-pandemic trends continue due to the effects of Brexit (Crafts, 2019), deteriorated balance sheets or persistent demand deficiencies, which could exert downward pressure on productivity growth.

\section{Trade}

Despite a smooth exit, Brexit is still expected to have long-term negative impact on the UK economy

As in our February forecast, we expect the conclusion of the Trade and Co-Operation Agreement negotiations with the European Union to remove a major source of uncertainty for the UK economy, though at a loss to future 
potential output. Hantzsche and Young (2019) estimated that in the long run the UK economy would be $31 / 2$ per cent smaller under an FTA deal compared to continued EU membership, mainly due to a reduction in trade and migration as well as weaker productivity growth.

Finance is likely to be among the worst affected sectors after having been relatively unscathed by Covid-19

Despite the significance of services trade for the UK, services provisions in the trade agreement are thin or even non-existent, as in the case of some financial services, implying a major change compared to the arrangements under the EU Single Market. This has potentially severe implications for air transportation, financial services and many professional and business services (Borchert and Morita-Jaeger, 2021). The lack of a trade agreement on services implies that the economic recovery cannot easily fall back on sectors like financial services which have been less exposed to the effects of Covid-19 (Ebell, 2017).

Brexit and Covid effects combined to create a dramatic fall in January goods trade

Some short-term impact of the Trade and Co-Operation Agreement was apparent in a reduction of trade of goods in January between the UK and the EU, after a period of stockpiling in the last quarter of 2020. Exports of goods to the EU fell by $£ 5.7$ billion (equivalent to a decrease of 42 per cent) in January, before partially recovering by increasing by $£ 3.7$ billion in February. Imports of goods from the EU dropped by $£ 6.7$ billion in January before partially recovering by increasing by $£ 1.2$ billion in February.

How much of this is permanent will become clear over the coming months as the economy fully re-opens

This did not constitute one-for-one trade diversion because trade with the rest of the world did not compensate for the fall in trade between the UK and the EU. Some of the reduction will have been caused by the new lockdown restrictions in January, though with GDP affected far less than last year this is unlikely to account for much of the reduction. Box A on page 18 considers the question of disentangling Brexit and Covid-19 effects from the point of view of firms' trading decisions.
Figure 1.20 Annual growth rates of UK labour productivity (GDP per hour worked)

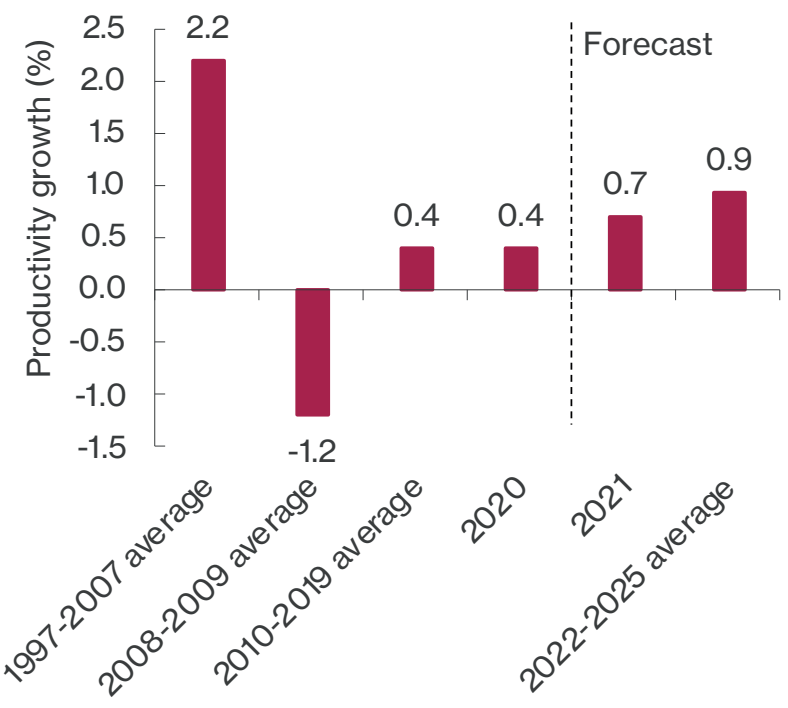

Source: ONS.

The UK is expected to follow the trend of a recovery in world trade growth in 2021. The domestic demand-led recovery is expected to lead to an increase in imports of 17 and 10 per cent in 2021 and 2022 respectively, after having fallen by 18 per cent in 2020. Exports are expected to recover more gradually, by around $7 \frac{1}{2}$ per cent and $11 \frac{1 / 2}{2}$ percent in 2021 and 2022 respectively, due to the higher cost of trading with the EU.

The medium-term effect is forecast to be a slight widening of the current account deficit

As a result, the current account balance is expected to worsen from a deficit of $3 \frac{1}{2}$ per cent of GDP in 2020 to around 5 per cent in 2021 and 2022. There are significant risks to our forecasts of exports and imports, depending on the extent of disruptions from Brexit and the pace of recovery from the pandemic across the world. 


\section{Box A The effects of Covid-19 and Brexit on firms' trading decisions}

\section{Manuel Tong Koecklin}

This box focuses on adjustments of firms' product trade portfolios, i.e. the number of products exported and inputs imported, and it looks at the literature on past crises and UK data to infer how UK businesses may be adjusting the range of products traded in response to the twin challenge of Covid-19 and Brexit. A key point is that this adjustment depends on firms' perception of the nature of these crises. Thus, firms tend to maintain their product portfolio when faced with temporary shocks and alter it when faced with permanent ones.

Naturally it is too early to draw solid conclusions with just two months of noisy data; there is a tendency to attribute this poor performance to the disruptions caused by the end of the transition period as the UK left the European Union (EU), preceded by the stockpiling of goods from some industries. However, this fall also coincided with the start of a national lockdown in January 2021 to contain the rise of Covid-19 infections. Hence, this panorama poses a huge challenge to researchers aiming to disentangle the effect of both shocks on UK trade.

First the facts: UK trade registered an unprecedented downturn in January 2021, with exports and imports of goods falling by 19.3 per cent and 21.6 per cent respectively compared with December 2020 (ONS, 2021a,b), although there was a slight recovery the following month. Most of this collapse has been driven by much lower trade with the EU (41 per cent and 28 per cent falls in exports and imports in January respectively).

A useful starting point is to understand the decision-making process at the firm level. Firms engaged in international trade decide on what to export, how much and where. Adjustments of these decisions in response to changes in the economic conditions shape the overall trade and output growth of a country. But these reactions depend on the perceived nature of these shocks, for instance, whether they are perceived as temporary or permanent.

Figure A.1 shows that in 2016 firms both exported and imported an average of eight goods. Clearly the larger the firm, the larger its product trade portfolio, with a sizeable gap between firms with over 250 employees and those below. Note though that these figures are average, which might conceal some skewness.

Figure A.1 UK Firms' Average Number of Goods Traded, 2016 (4-digit commodity codes)

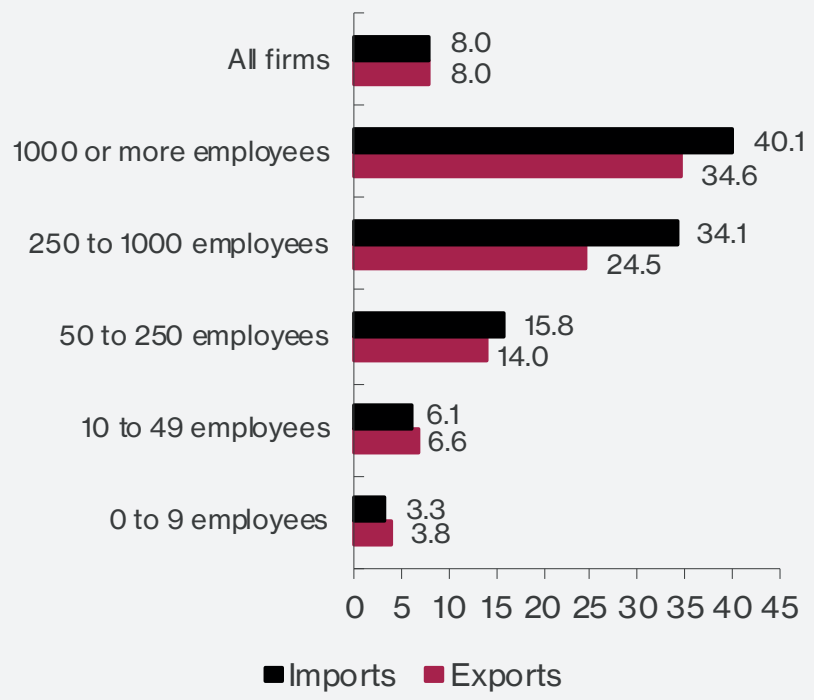

Note: Excluding wholesale and retail industries Source: HMRC, ONS, NIESR calculations.
Besides this, Figure A.2 indicates that firms' product mixes vary considerably across sectors, with manufacturing industries such as transport equipment, pharmaceuticals, chemicals and mining tending to trade more products than industries like agriculture, food, beverages and tobacco.

ONS-HMRC figures also show that in 2016 UK firms tended to trade fewer products with the EU than with the rest of the world, but data on EU trade is limited by a threshold which might conceal more products. ${ }^{5}$

This was the picture in the year the UK decided to leave the EU. ${ }^{6}$ How might these figures have changed due to the twin challenges of Covid-19 and Brexit? We should bear in mind the perceived nature of each.

An early study on the global effects of Covid-19 (Antràs, 2020) argues that there is not yet evidence of an era of 'de-globalisation', since firms view Covid-19 as a temporary shock, after which the 'global value chain' will gradually return to its usual form. As a result, firms are mainly responding by trading smaller volumes of their existing products, rather than adding or dropping products from the market. Nevertheless, the study warns it is not clear yet whether Covid-19 can be labelled as a

\footnotetext{
5 The figures do not consider UK firms with trade with the EU below a threshold from the Intrastat survey. In 2016, those thresholds were $£ 1.5$ million for arrivals and $£ 250,000$ for dispatches.

6 There have not been further reports on products traded per firm since the 2018 ONS report with 2016 data.
} 
temporary shock due to continuous disruptions of business travel services and increasing income inequality from divergent abilities to work from home (see Chapter 2).

Figure A.2 UK Firms' Average Number of Goods Traded by Industry, 2016 (10+ employees, 4-digit commodity codes)

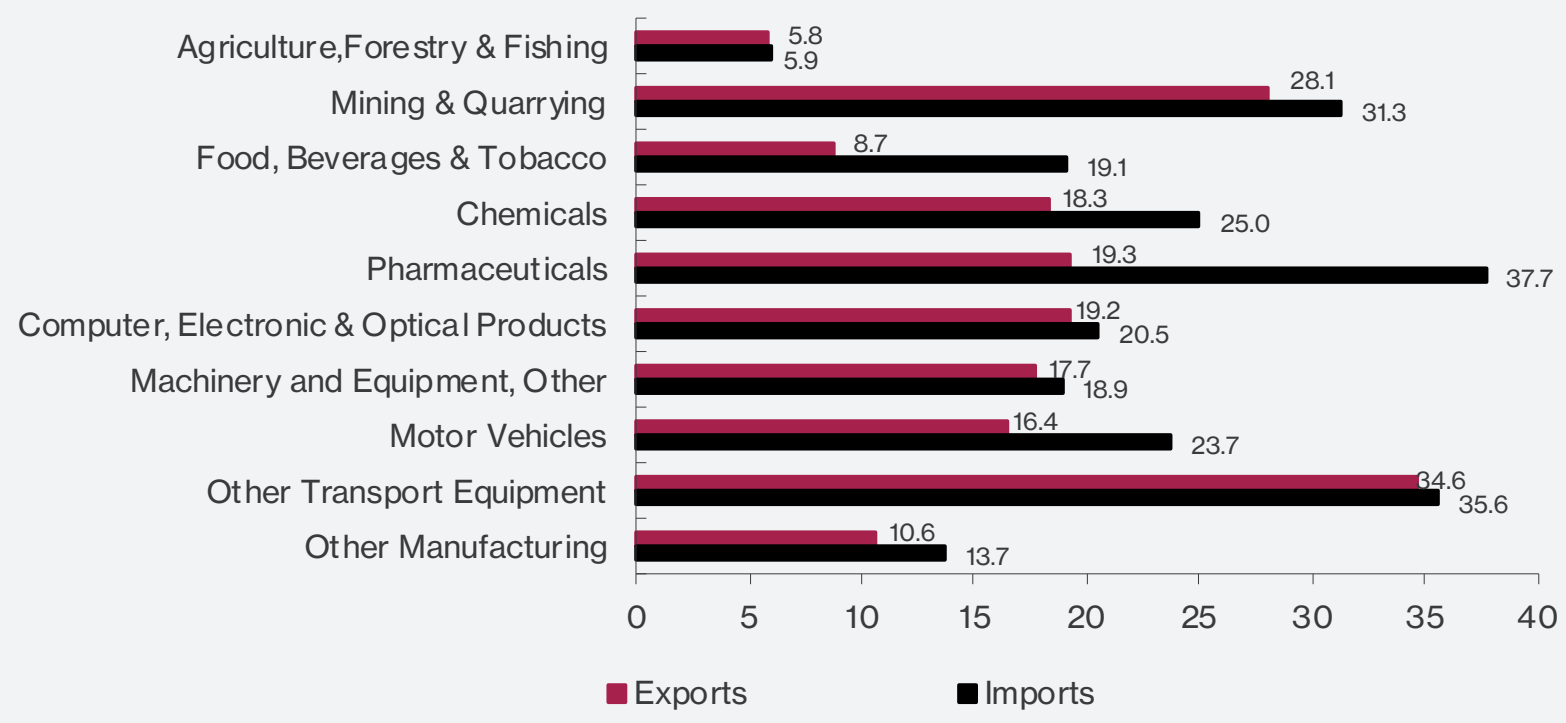

Note: A, Agriculture, Forestry \& Fishing; B, Mining \& Quarrying; C 10-12, Food, Beverages \& Tobacco; C 20, Chemicals; C21, Pharmaceuticals; C 26, Computer, Electronic \& Optical Products; C 28, Machinery and Equipment, Other; C 29, Motor Vehicles; C 30, Other Transport Equipment; C Other, Other Manufacturing

Source: NiGEM simulation.

These conclusions are in line with the literature on past crises, such as the Great Recession in 2008-09, for countries like Belgium (Behrens et al., 2013) and Denmark (Abreha et al., 2013). The reason is that it is very costly for firms to shut down links with existing partners and search for others. These rigid production networks make links react sluggishly to trade shocks, as occurred in Chile during the Great Recession in 2008-09 (Hunneus, 2018). Moreover, some products have higher partner search costs than others (Martin et al., 2020). Hence, links remain active, but with smaller volumes of the same products.

Conversely, Brexit is generally seen as a permanent shock since it constitutes a permanent rise in trading costs with the EU. The literature on permanent trade shocks converges around the argument that changes in firms' product mixes are pervasive. This has been found in the case of China in response to institutional reforms (Söderbom and Weng, 2012) and the reduction of tax rebates (Han et al., 2015). There is also theoretical support when analysing unexpected changes in input tariffs (Grossman and Helpman, 2020). Hence, it is reasonable to expect long-run adjustments in UK firms' product portfolio in the EU market, dropping the least competitive products in response to Brexit. For instance, firms might drop the costliest goods to produce and export from sectors like machinery, transport equipment and chemicals, which saw the largest falls in trade with the EU early this year (ONS, 2021 a,b).

It is worth bearing in mind as well that the high degree of uncertainty caused by Brexit has been remarked on by studies of its short-run, post-referendum effect. Such uncertainty has led to delays in firms' investment decisions (Bloom et al., 2019) and some firms deciding against trading in the EU market, but without causing a huge aggregate effect (Crowley et al., 2018). The former study also remarks that UK firms reported reduced investment in machinery, equipment and buildings and, to a lesser extent, in training, software and R\&D. Additionally, recent trade data shows that UK exports in agricultural products, chemicals and some manufacturing industries (rubber, leather, silk, among others) fell the most between 2016 and $2020 .^{7}$

7 See coriolistechnologies.com 
Considering the perceived natures of Covid-19 and Brexit, along with the experience from previous crises, it is arguably the case that the long-run Brexit effects will prevail in firms' product mix decisions, translating into fewer products being traded with the EU. However, much more information is required to disentangle the effects of both shocks and draw more evidence-based conclusions. And while it is not clear how trade in services with the EU will be affected in terms of number of services traded, the lack of a clear service sector deal raises questions for future research and policy-making.

In that sense, efforts to retrieve and analyse more real-time data are valuable. Research involving input from NIESR found a sustained drop in the number of UK exporters by May 2020 (around 2 per cent relative to May 2019) amid the first national lockdown, mostly accounted for by small and micro enterprises, which have less access to trade finance than larger firms. ${ }^{8}$ Despite the recovery afterwards, figures have not returned to pre-Covid levels. According to the same data, one of the most up to date sources for trade activity, Northern Ireland is the worst hit among UK regions, despite remaining in the EU single market for goods. This is a useful reminder that differences across regions and sectors are also essential to depict a more complete picture of the effects of the twin challenges to UK trade.

\section{REFERENCES}

Abreha, K.G., Smeets, V. and Warzynski, F., 2013. Economics Working Papers.

Antràs, P., 2020. De-Globalisation? Global Value Chains in the Post-COVID-19 Age (No. w28115). National Bureau of Economic Research.

Behrens, K., Corcos, G. and Mion, G., 2013. Trade crisis? What trade crisis?. Review of economics and statistics, 95(2), pp.702-709.

Bloom, N., Bunn, P., Chen, S., Mizen, P., Smietanka, P. and Thwaites, G., 2019. The impact of Brexit on UK firms (No. w26218). National Bureau of Economic Research.

Crowley, M., Exton, O. and Han, L., 2018, July. Renegotiation of trade agreements and firm exporting decisions: evidence from the impact of Brexit on UK exports. In Society of International Economic Law (SIEL), Sixth Biennial Global Conference.

Grossman, G.M. and Helpman, E., 2020. When Tariffs Disturb Global Supply Chains (No. w27722). National Bureau of Economic Research.

Huneeus, F., 2018. Production network dynamics and the propagation of shocks. Princeton University.

Martin, J., Mejean, I. and Parenti, M., 2020. Relationship stickiness and economic uncertainty. Mimeo.

ONS, 2018. UK trade in goods and productivity: new findings, https://www.ons.gov.uk/economy/economicoutputandproductivity/ productivitymeasures/articles/uktradeingoodsandproductivitynewfindings/2018-07-06

ONS, 2021a. UK Trade: Fanuary 2021, https://www.ons.gov.uk/economy/nationalaccounts/balanceofpayments/bulletins/uktrade/ january 2021

ONS, 2021b. UKTrade: February 2021, https://www.ons.gov.uk/economy/nationalaccounts/balanceofpayments/bulletins/uktrade/ february 2021

Söderbom, M. and Weng, Q., 2012. Multi-product firms, product mix changes and upgrading: Evidence from China's stateowned forest areas. China Economic Review, 23(4), pp.801-818.

Tan, Y., Han, J. and Ma,Y., 2015. Multi-product firms, product scope, and the policy of export tax rebate. China economic review, 35, pp.33-46.

8 A project developed with funding from Innovate UK and led by Coriolis, see note 3. 


\section{Box B Interest rate rises and Covid-19 government debts}

By Rory Macqueen ${ }^{9}$

The $£ 300$ billion deficit in 2020-21 did not seem to present a significant financing problem for the government. ${ }^{10}$ Over the same period a further $£ 440$ billion of government debt purchases were authorised as part of the Bank of England's quantitative easing programme. This took the Monetary Policy Committee's (MPC) target for government debt purchases through the Asset Purchase Facility (APF) to $£ 875$ billion, or some 40 per cent of public sector net debt outstanding, though the face value of holdings is lower. ${ }^{11}$

The increase in government debt will translate into an increased sensitivity of any debt service costs to interest rate changes, thoug the level of service costs remains low (see Figure 1.23 on page 26). This March, the Office for Budget Responsibility (OBR) projected the annual direct cost of one percentage point higher interest rates was over $£ 20$ billion after five years (see Table B.3 below), something also alluded to by the Chancellor in his Budget speech, ${ }^{12}$ and ten-year treasury yields rose by around 50 basis points in the first few months of 2021 . But it is the cause of the increase in interest rates that matters when we consider the effect on the fiscal balance. Should any rises in gilt yields rises be driven by higher growth, tax receipts will increase, and the debt burden may fall despite rising borrowing costs. For example, as a rule of thumb, with a tax-GDP ratio in the region of 40 per cent, one per cent higher nominal GDP would equate to an increase in tax receipts in the region of $£ 10$ billion per year.

To place interest rate rises of the order cited by the Chancellor in their economic context, we used the Institute's NiGEM model to simulate two scenarios in which rate rises of one percentage point may take place: (1) a positive GDP shock and (ii) a negative term premia shock. No other variables are shocked, and we assume that in both cases the stock of QE each year is unchanged from the OBR baseline - a strong assumption, but one which also underpins the OBR estimates of rising interest rate costs so is preserved here to aid comparison.

These simulations and further NIESR analysis suggest that:

- A positive demand shock will benefit the public finances immediately, but that this benefit may be reduced by the large stock of quantitative easing, as higher interest rates will be paid on reserves.

- A shock to term premia will raise long-term interest rates and impair the public finances accordingly but gradually as new debt is issued or rolled over. If Bank Rate is unaffected, the stock of QE has no negative fiscal impact.

- What matters for the public finances is the nature of the shock, the stock of QE purchases and the fiscal framework. Given the low level of long-term funding costs, any negative impacts are likely to be a small proportion of GDP.

- Should HM Treasury remain concerned about fiscal risks from interest rate volatility there are steps they can take to limit this, which could involve draining reserves or swapping them for short term T-bills.

\section{Two scenarios}

In our first stylised scenario we use a baseline model without a quantitative easing channel to simulate a strong increase in consumption expenditure that leads to a persistent rise in inflation and an immediate and dramatic rise in Bank Rate which, in turn, feeds through immediately to long-term rates. This takes the form of a calibrated shock to household consumption of 4 per cent, falling gradually to 2 per cent over the forecast period, implying a household savings rate sharply lower but firmly within the range described in the discussion on page 14 .

In the second scenario, instead of a demand-driven boom, there is a loss of confidence in the UK's monetary-fiscal framework such that investors demand increased compensation for holding UK gilts. This raises the term premia by a sufficient degree to match the rises in long-term rates in Scenario 1. This credibility shock has a negative impact

9 The author would like to thank Jagjit Chadha for helpful comments.

10 See Chadha et al (2021)

11 See, for example, Giles, C. and Stubbington, T. 'Investors sceptical over Bank of England's QE programme', Financial Times 5 January 2021, which reported that "investors believe the central bank's quantitative easing programme is a thinly veiled attempt to finance the government's deficit to keep its borrowing costs down".

12 OBR 'Economic and Fiscal Outlook', March 2021, supplementary fiscal table 3.23 
on the UK economy and the Bank of England responds by slightly reducing short-term interest rates. ${ }^{13}$ As in the first scenario we begin by assuming no quantitative easing effects.

Figure B.1 shows the resultant increases and decreases in public borrowing; Figure B. 2 shows the effect on the government's interest payments as a share of GDP. Any additional interest costs in the first scenario are comfortably outweighed by the positive fiscal consequences of higher growth: public sector borrowing is $£ 15$ billion lower in the first year and $£ 4$ billion lower after five years. Rising interest rates tend to dampen expansion, but overall the public finances are better off as a result of the positive consumption shock and public sector debt is lower (see Table B.1).

The second scenario might be of greater concern, especially as it is associated with lower nominal GDP which effectively raises the level of debt relative to the economy. However, total interest payments are a small proportion of GDP under any scenario, and the size of the shock - at around an additional 0.3 percentage points of GDP - is even smaller. ${ }^{14}$ Fiscal pressures may be greater in this situation, however, which relates to our discussion of the fiscal framework on pages $26-7$.

\section{Introducing the fiscal effects of quantitative easing}

These results notably do not include the effects of the build-up of a large stock of government debt held by the Bank of England after four rounds of quantitative easing. Effectively this has led to around a third of UK government debt being re-financed at short term rates. This distorts the fiscal calculus because Asset Purchase Facility acquisitions are made in exchange for newly-created Bank of England reserves which, since 2008, pay interest at Bank Rate. The APF returns to the Treasury any profit it makes on the margin between that and the interest rates on its gilt holdings ${ }^{15}$. NIESR discussion of this issue can be found in Allen (2021), which seeks to address the resultant interest rate volatility of government debt. Any effect which QE has had on economic growth and government gilt rates over the past ten years - not modelled here - should also be factored into any estimates of its overall long-run fiscal impacts. ${ }^{16}$

We can add to the above 'No QE' results and the impact of the APF holding a proportion of debt which is remunerated at Bank Rate. By separating the debt stock into these two portions a 'QE effect' is calculated and added to the modelled scenarios' changes to the public finances. ${ }^{17}$ Figures B. 3 and B.4 show the fiscal consequences of the QE holdings compared with the previous scenarios, as well as the net impact on the public finances of the shock with QE effect overlaid.

In Scenario 1, the remuneration of reserves following a rise in Bank Rate would negate much or all of the fiscal benefit from the shock, though the net 'costs' would also still be, at around $£ 2$ billion annually after five years, an order of magnitude smaller than headline figures from the OBR projections of the direct costs of interest rate rises (see Table B.3).

Note though that in considering the impact of quantitative easing, any losses which did materialise now must be set against the significant savings which QE has already produced for the government. Its estimated fiscal benefit for 2021-22 has been forecast by the OBR at $£ 17.8$ billion and $£ 110$ billion of transfers have already been made from the APF to HM Treasury between 2013 and 2020. In a sense any future losses have been funded.

13 This makes little difference to the results in Figure B.3, where the 'QE effect' comes from the small but gradually increasing return to the APF from maturing gilts which are rolled over at higher interest rates. Tax rates and the real exchange rate are treated as exogenous for the forecast period in both cases.

14 Much of the early 2021 rise in yields is likely to have been driven by similar rises in US treasuries, so strictly speaking the pertinent question may be whether they will be accompanied by higher UK growth in future, rather than whether they are driven by expectations of it.

15 After reinvesting the proceeds of redeemed gilts and a 'redemption loss' which arises from gilts having been purchased above par. For more information see Office for Budget Responsibility, 'The direct fiscal consequences of unconventional monetary policies', March 2019, in particular footnotes 8 and 10, and Section 3.1 of the Independent Evaluation Office 'IEO evaluation of the Bank of England's approach to quantitative easing', January 2021.

16 See Chadha, J., Corrado, L., Meaning, J. and Schuler, T. (forthcoming) 'Monetary and fiscal complementarity in the Covid-19 pandemic', Centre for Macroeconomics working paper

17 Although interest rates may fall below zero, we do not assume that this is imposed on bank reserves: if it were the positive fiscal impact of QE in Scenario 2 would be slightly greater. We also assume that APF gilts are representative of the debt stock as a whole: in fact they exclude index-linked gilts but have longer-than-average maturity, which act as small biases in opposing directions. 


\begin{tabular}{lrccccc}
\hline Table B.1 & \multicolumn{3}{c}{ Scenario 1- Demand recovery } & \multicolumn{2}{c}{ percentage point difference from baseline } \\
\hline Fiscal year & $\begin{array}{c}\text { Bank } \\
\text { Rate }\end{array}$ & $\begin{array}{c}\text { Long- } \\
\text { term rate }\end{array}$ & $\begin{array}{c}\text { CPI } \\
\text { inflation }\end{array}$ & $\begin{array}{c}\text { Government borrowing } \\
\text { as a share of GDP }\end{array}$ & $\begin{array}{c}\text { Government debt as a } \\
\text { share of GDP }\end{array}$ & $\begin{array}{c}\text { Government debt } \\
\text { interest as a share of } \\
\text { GDP }\end{array}$ \\
\hline $\mathbf{2 0 2 1 - 2 2}$ & 0.8 & 0.9 & 0.2 & -0.8 & -2.1 & 0.0 \\
$\mathbf{2 0 2 2 - 2 3}$ & 1.1 & 0.9 & 0.7 & -0.3 & -2.5 & 0.1 \\
$\mathbf{2 0 2 3 - 2 4}$ & 1.0 & 0.9 & 0.6 & -0.2 & -3.2 & -3.7 \\
$\mathbf{2 0 2 4 - 2 5}$ & 1.0 & 0.8 & 0.4 & -0.2 & -4.0 & 0.1 \\
$\mathbf{2 0 2 5 - 2 6}$ & 0.9 & 0.8 & 0.3 & -0.3 & & 0.2 \\
\hline
\end{tabular}

Table B.2 Scenario 2 - Term Premia shock

percentage point difference from baseline

\begin{tabular}{lcccccc}
\hline Fiscal year & $\begin{array}{c}\text { Bank } \\
\text { Rate }\end{array}$ & $\begin{array}{c}\text { Long- } \\
\text { term rate }\end{array}$ & $\begin{array}{c}\text { CPI } \\
\text { inflation }\end{array}$ & $\begin{array}{c}\text { Government borrowing } \\
\text { as a share of GDP }\end{array}$ & $\begin{array}{c}\text { Government debt as a } \\
\text { share of GDP }\end{array}$ & $\begin{array}{c}\text { Government debt } \\
\text { interest as a share of } \\
\text { GDP }\end{array}$ \\
\hline $\mathbf{2 0 2 1 - 2 2}$ & -0.1 & 0.9 & 0.0 & 0.2 & 0.5 & 0.1 \\
$\mathbf{2 0 2 2 - 2 3}$ & -0.2 & 0.9 & -0.2 & 0.5 & 1.6 & 0.1 \\
$\mathbf{2 0 2 3 - 2 4}$ & -0.2 & 0.9 & -0.5 & 0.5 & 2.7 & 0.2 \\
$\mathbf{2 0 2 4 - 2 5}$ & -0.3 & 0.8 & -0.6 & 0.4 & 3.5 & 0.3 \\
$\mathbf{2 0 2 5 - 2 6}$ & -0.4 & 0.8 & -0.4 & 0.2 & 3.8 & 0.3 \\
\hline
\end{tabular}

Figure B.1 Impact on public sector borrowing of shock scenarios 1 and 2

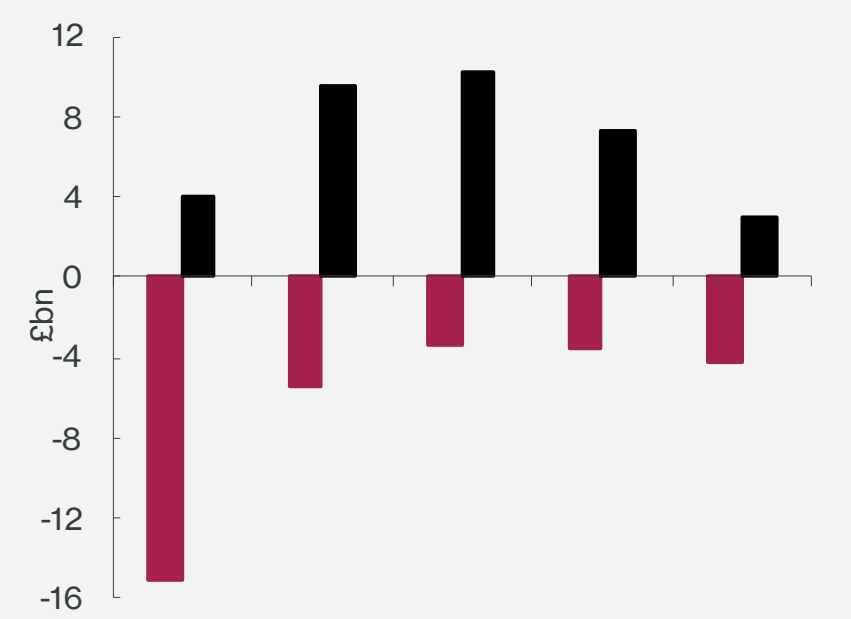

2021-22 2022-23 2023-24 2024-25 2025-26

- Scenario 1 Scenario 2
Figure B.2 Impact of government interest payments of shock scenarios 1 and 2

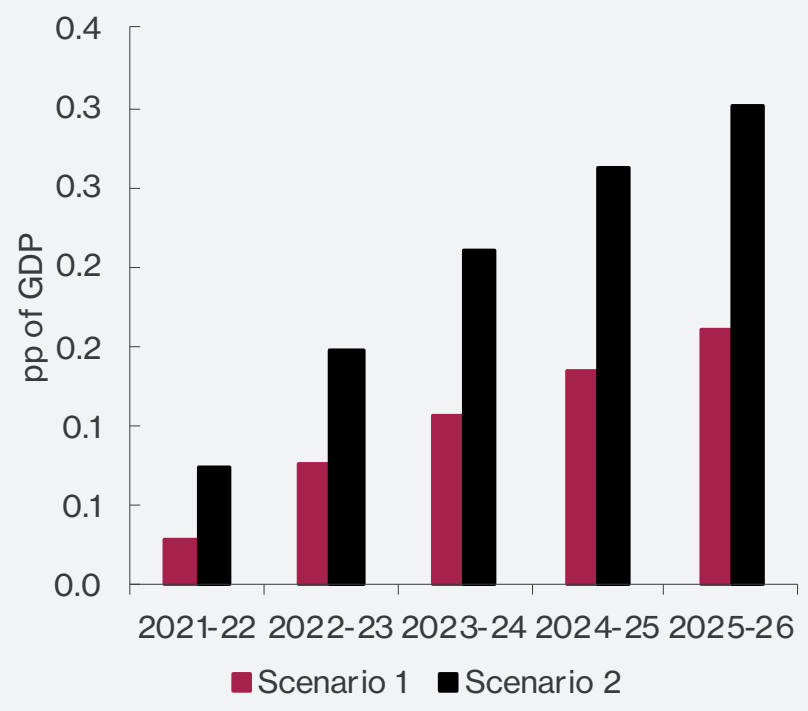

Source: NiGEM simulation. 


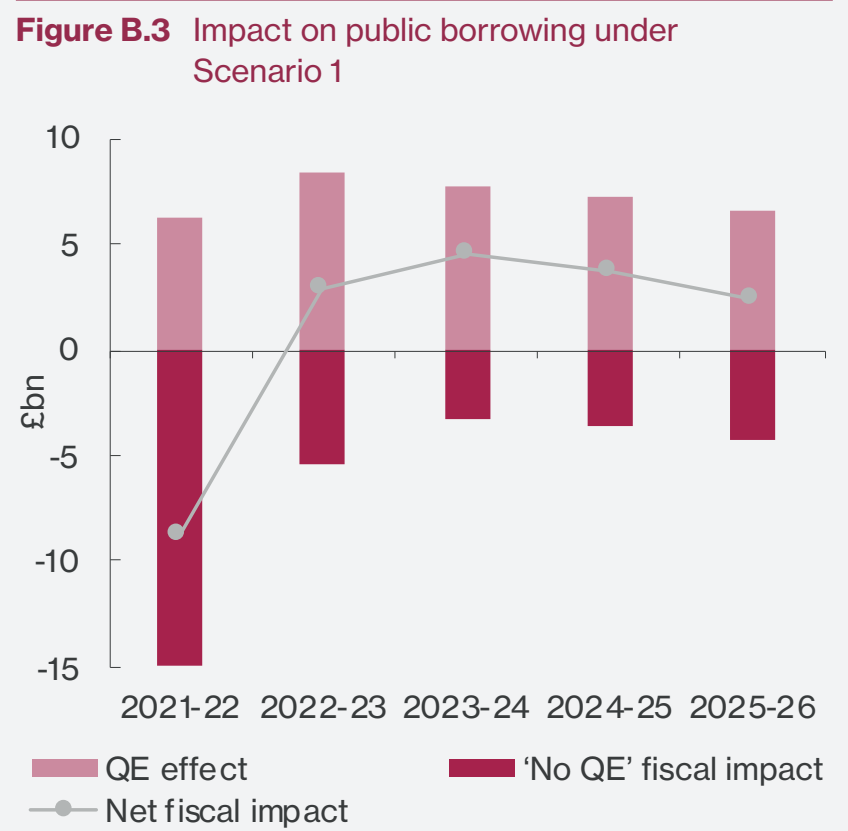

Source: NiGEM simulation.
Figure B.4 Impact on public borrowing under Scenario 2

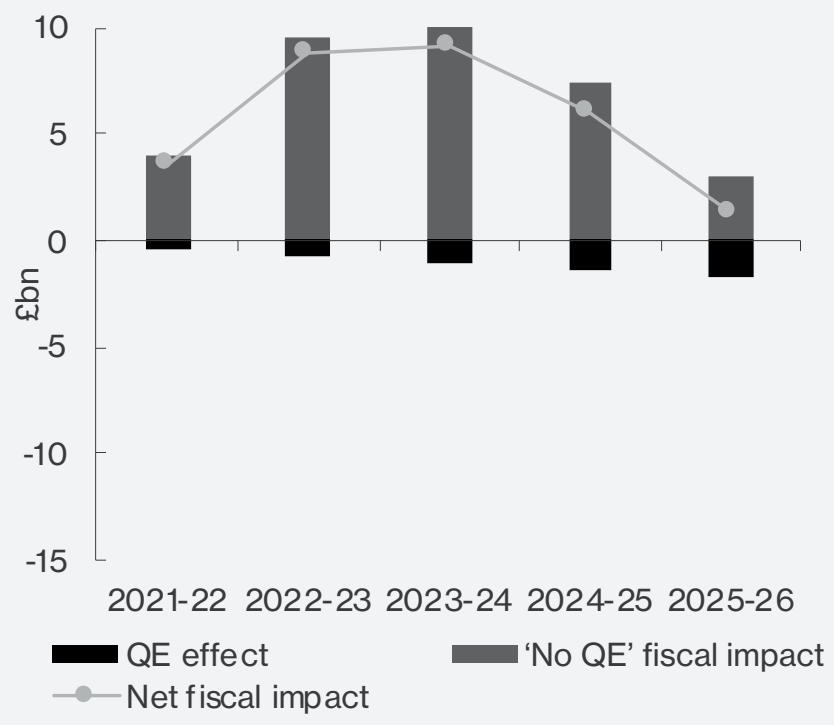

Source: NiGEM simulation.

Table B.3 Fiscal impacts of rises in short- and long-term interest rates

$£$ billion

\begin{tabular}{lccccc}
\hline & $\mathbf{2 0 2 1 - 2 2}$ & $\mathbf{2 0 2 2 - 2 3}$ & $\mathbf{2 0 2 3 - 2 4}$ & $\mathbf{2 0 2 4 - 2 5}$ & $\mathbf{2 0 2 5 - 2 6}$ \\
\hline $\begin{array}{l}\text { Direct fiscal impact (OBR) } \\
\text { 1 percentage point increase in gilt rates }\end{array}$ & -1.1 & -3.2 & -5.1 & -7.0 & -8.9 \\
$\begin{array}{l}\text { 1 percentage point increase in short rates } \\
\text { Net fiscal impact incorporating QE impact }\end{array}$ & -11.7 & -11.8 & -11.8 & -11.9 & -11.9 \\
$\quad$ & & & & -2.3 \\
$\quad \begin{array}{l}\text { Scenario 1: demand shock to all interest } \\
\text { rates }\end{array}$ & 8.8 & -2.9 & -4.4 & -3.6 & -3.3 \\
\hline Scenario 2: confidence shock to gilt rates & -2.5 & -7.1 & -7.6 & & 2.6 \\
\hline
\end{tabular}

A key assumption in these calculations is that of an APF stock unchanged from the baseline scenario. In reality, faced with a need to tighten policy, the MPC may decide to sell APF gilts back to the private sector; indeed it may seem counterintuitive that the MPC would raise Bank Rate by as much as one percentage point without allowing its APF holdings to fall. Formerly it was policy "not to reduce the stock of purchased assets until Bank Rate reaches around 1.5 per cent" (Carney, 2018) but, since then, rates have fallen further and the APF has expanded further; Governor Bailey suggested in summer 2020 that bond sales could precede rate rises ${ }^{18}$ and the policy is currently under review, as discussed in Box C.

More importantly, were short-term rates to rise this far and fast, the current QE framework would likely be called into question. Allen (2021) proposes to reduce reserves at floating rates ahead of time by exchanging them for newly-issued short-term gilts. Other proposed alternatives include the tiered remuneration of reserves (Lord Turner, quoted in Giles, 2021), creation of new central bank reserves (Kyriakopoulou et al, 2020) and Special Deposits or money creation (Holtham, Chapter 6 in Chadha, et al (2021)).

In the second scenario where the rise in gilt yields is driven by a term premia shock, there would be little incentive to unwind or change the QE framework. As shown in Figure B.3, the fact that the rolling over of APF-held debt at higher rates makes the contribution of QE to the net fiscal impact of the shock a small but positive one, compared with a 'no QE' counterfactual.

18 The same questions have been discussed by the US Federal Reserve: see 'History of the FOMC's Policy Normalization Discussions and Communications', https://www.federalreserve.gov/monetarypolicy/policy-normalization-discussions-communications-history.htm 


\section{REFERENCES}

Allen, W. (2021) 'Managing the fiscal risk of higher interest rates', NIESR Policy Paper 25, March

Carney, M. (2018) 'New economy, new finance, new Bank', Mansion House speech, 21 June

Chadha, J., Küçük, H. and Pabst, A. (Eds.) (2021) Understanding and confronting uncertainty: new fiscal and monetary policy interactions, NIESR Occasional Papers LXI, April

Giles, C. (2021) 'Banks should fear a stealth tax in a post-pandemic boom', Financial Times, 1 April

Kyriakopoulou, D., Ortlieb, P. and Papadopoullos, C. (2020) 'Fiscal danger of interest on reserves overblown', OMFIF blog, 7 December

\section{Fiscal policy}

Government spending stepped in to protect the economy when the pandemic reached the UK...

The public sector has played a crucial role in tackling the Covid-19 pandemic though increased nominal spending was not reflected in output data last year. With the cancellation of routine appointments and other work, despite significant increases in spending, government consumption fell by 6.5 per cent in real terms in 2020 . In contrast an expansion of testing and vaccination programmes is likely to have contributed to growth in the first quarter of 2021: output in the 'Human health and social work activities' sector (including both public and private) grew by 6 per cent month-on-month in January alone.

Figure 1.21 Cross-country comparison of health resources pre-Covid

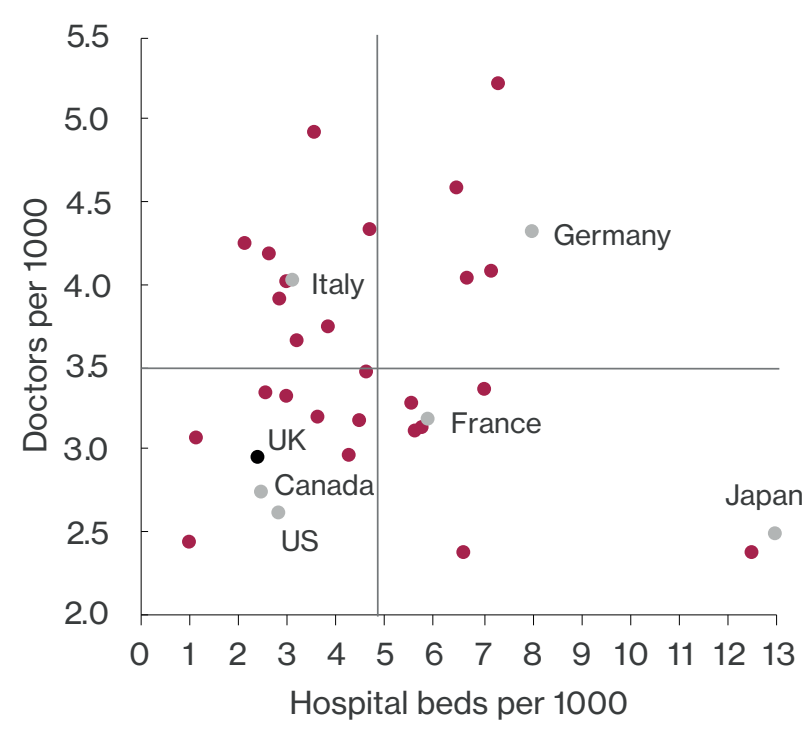

Note: Horizontal and vertical lines indicate averages. Source: OECD, Health Foundation. ...but too little spending previously is likely to have contributed to 2020's high Covid-19 mortality rates...

The weak state of the UK's health and social care sectors in the face of the Covid-19 pandemic is not unrelated to the decade of public spending restraint which preceded it. Though far from being the only factor, the Health Foundation (Idriss and Rocks, 2020, Figure 1.21) find links between hospital capacity and Covid-19 mortality rates; out of 33 countries studied only three had fewer hospital beds per person than the UK, which also performed poorly in measures of doctors per person and critical care beds per person.

...with economic and therefore fiscal consequences

Given that one of the main determinants of the UK's relatively large recession in 2020 was the high incidence of Covid-19, if the unprepared nature of the health and social care sectors exacerbated that, there is a clear economic and fiscal case for more investment in capacity to prepare the UK for any future public health shocks of the sort.

Peacetime records for borrowing were shattered as a result

The combination of the large fall in GDP and the rise in government spending contributed to public sector borrowing of $£ 303$ billion in 2020-21, an estimated 14.5 per cent of GDP, though with the write-offs of public loans to be accounted for these figures are subject to revision. Public sector net debt is estimated to have been $£_{2} 2,142$ billion, just under 98 per cent of GDP, subject to similar revisions.

Tax rises have been announced for two years' time alongside immediate cuts to spending plans

The Budget on 3 March announced further Covid-related spending this year, most notably the extension of labour market support discussed earlier. This has contributed to our upward revisions to overall growth expectations this year. The government announced fiscal consolidation for future years: downward revisions to the departmental spending envelope ahead of the expected Spending Review were made at both of the last two fiscal events, while the headline rate of corporation tax will rise to 25 per cent in 2023. 
But in the short term an investment superdeduction was announced alongside more Covid-19 related spending

As discussed on page 15, the corporation tax increase will follow a two-year 'superdeduction' of investment in plant and machinery from corporate tax liabilities. We estimate the fiscal consequences of this package to be relatively small in the short term, due to the smoothing of investment plans.

We forecast a return to pre-Covid borrowing levels in three years' time, driven by the economic recovery... Our forecast incorporates the announced changes to effective tax rates and spending policy but tax receipts are sensitive also to GDP forecasts, which in our main case are stronger than both our February forecasts and those made by the OBR in March. As a result, in our main case forecast scenario public sector borrowing falls relatively quickly, reaching to 9.6 per cent of GDP this fiscal year and 5.5 per cent in $2022-23$, returning close to its preCovid level in 2024-25.

... and opening up the possibility of further loosening at the end of this parliament

In this scenario the current budget deficit falls below 2 per cent in 2023-24, raising the possibility of fiscal loosening ahead of the next General Election, which is scheduled to take place in 2024. If the economic recovery follows this path we could see a higher path for government consumption, or the cancellation or reduction of the planned increase in corporation tax, but neither is assumed in our forecasts.

Figure 1.22 Public sector net debt

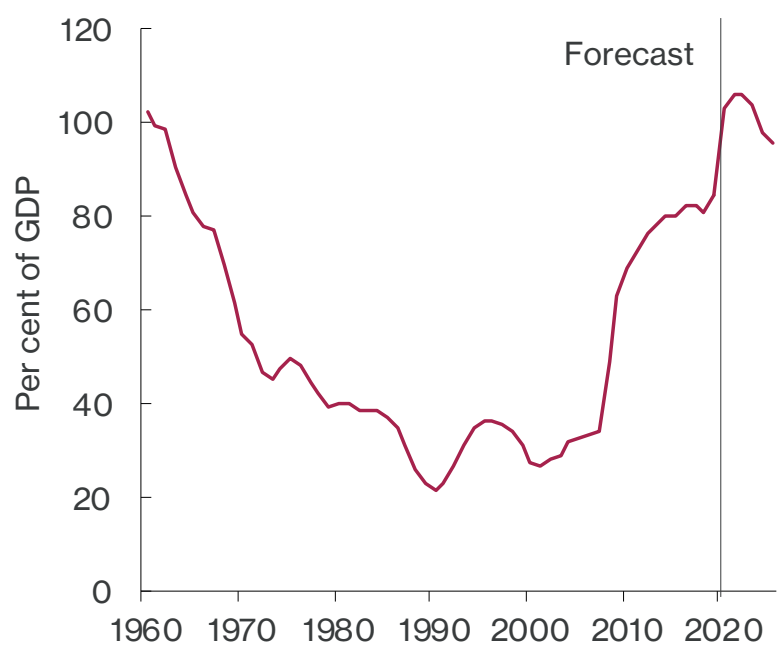

Source: ONS, NIESR forecast.
Debt remains around 104 per cent for the next two years...

The interaction of the paths for tax rates and spending with our main case forecast scenario for GDP means that debt is forecast to reach 104 per cent of GDP in 2022-23, falling after this, aided by the expected end of the Term Funding Scheme in 2024 (see Figure 1.22).

...with no negative consequences for fiscal sustainability in our main case scenario

Government debt interest payments continue to fall as a share of GDP, as seen from the narrowing of the wedge between the deficit and primary deficit in Figure 1.23 , driven by continued low interest rates. The cost of government debt is reduced by the Bank of England's quantitative easing programme, which effectively refinances borrowing at short-term rates for as long as gilts are held by the Bank of England. Box B on page 21 examines some consequences of the increase in debt and its sustainability under different circumstances.

Fiscal rules should not be tied to parliamentary cycles or lead to sharp changes in taxes or spending...

NIESR Occasional Paper 61 (Chadha et al, 2021) focuses on the appropriate design of a new fiscal framework for the UK. Finding a right balance between flexibility to respond to changing economic circumstances and the credibility to maintain control of debt is at the heart of any fiscal framework: rules-based policies impose both external and internal discipline for fiscal policy, and ensure that economic agents condition on the government's

Figure 1.23 Public sector borrowing and primary balance

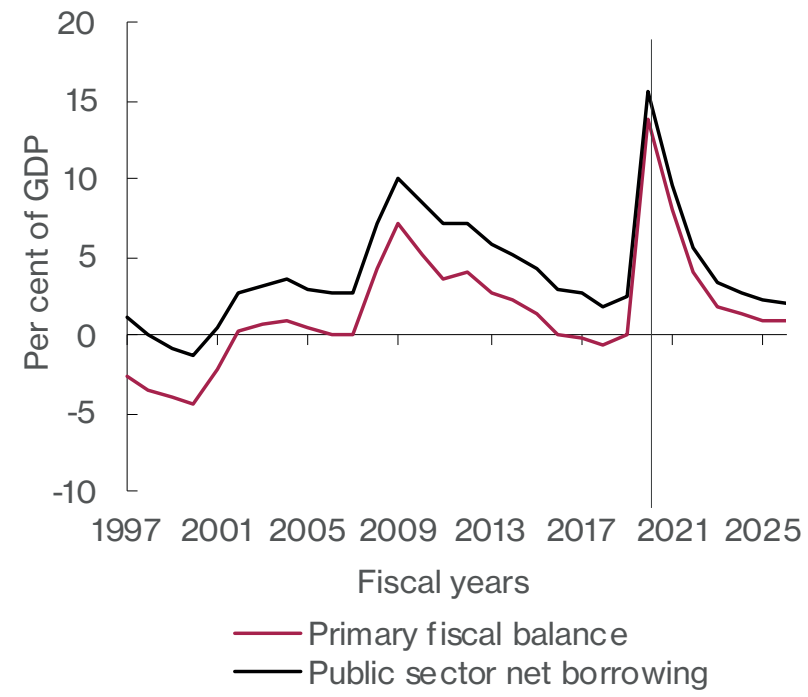

Source: NiGEM database, NIESR forecast. 
plans, but fiscal rules are presently tied excessively to parliamentary cycles.

The headline fiscal position, for which targets are set, depends heavily on a business cycle that is not fully known or understood in real time, implying that taxes and spending could be adjusted sharply in response to minor changes in forecast assumptions or in the face of small shocks, with adverse effects for the welfare of citizens and communities. Fiscal policy ought to be to be assessed in terms of a social welfare function not in terms of a deficit or debt position alone.

...but should incorporate wider considerations, including distributional effects, well-being and sustainability

Firstly, a new approach to fiscal events should follow a stricter timetable with greater parliamentary scrutiny, a clearer focus on the state of the economy and a more granular analysis of the socio-economic implications of policy choices. Secondly, we recommend that the OBR publish pre-fiscal event reports with key issues to which the Budget and the Autumn Statement should respond. Thirdly, in light of uncertain economic cycles, the Chancellor should outline government thinking about fundamental fiscal choices in different economic scenarios and the OBR should be encouraged to state whether these are reasonable and aligned with social welfare given the economic outlook. Fourthly, HM Treasury should create a new body of independent experts for ex ante advice and ex post evaluation of the key fiscal choices, moving from descriptive fiscal policy to a formal assessment of normative choices. And finally, fiscal strategy ought to be joined up across the UK and all its constituent parts, with particular attention paid to distributional effects, productivity, well-being and ecological sustainability.

\section{Prices and monetary policy}

\section{Inflation is rising thanks to demand pressures and base effects}

Annual headline inflation increased to 0.7 per cent in March, from 0.4 per cent in February, but largely unchanged from 0.6 per cent recorded in December 2020. Underlying inflation measured by the trimmed mean (which excludes 5 per cent of the highest and lowest price changes) increased to 0.6 per cent in March, recording its highest level since October (see National Institute Monthly CPI Tracker, April 2021). NIESR's lockdownweighted CPI fell slightly to 0.8 per cent in March from 0.9 per cent in February.

It has been restrained by sterling rises but will pick up further later in the year as the economy recovers

Despite the sharp rise in the dollar price of international commodities in the first quarter of 2021, which is expected to continue to a lesser degree into the second quarter, the continued appreciation in the sterling exchange rate has limited the rise in import costs. As the consumptiondriven recovery gains pace we expect a gradual rise in the capacity utilisation rate from the second quarter, leading to higher levels of inflation compared to recent quarters. Base effects will initially support a rise in annual inflation, as price increases during the first lockdown were lower than historical averages, but later in the year they will work in the opposite direction.

We expect CPI inflation to reach close to, but remain below, its 2 per cent target in each year of the forecast In our main-case scenario, we forecast CPI inflation to rise to 1.8 per cent in the last quarter of 2021 , rising briefly before falling back to 1.5 per cent by the end of 2022 as temporary factors dissipate (see Figure 1.24). Inflation then remains close to but below its 2 per cent target in each year between 2023 and 2025. These forecasts not only reflect our views on medium-term spare capacity but also indicate weak trends in underlying inflation despite the stronger wage growth and weaker productivity growth observed before the pandemic (Tenreyro, 2020).

\section{Inflation risks exist, linked to upside risks to household consumption}

However, the balance of risks around our main-case forecasts includes the possibility of higher inflation driven by a stronger than expected recovery in consumption possibly led by a faster unwinding of accumulated savings as we emerge from the pandemic on the back of a successful vaccination programme. Macqueen (2020a) presents an upside risk scenario assuming consumption recovers more quickly -3 per cent above the baseline this year and next - and shows that inflation might increase more rapidly

\section{Figure 1.24 Inflation fan chart}

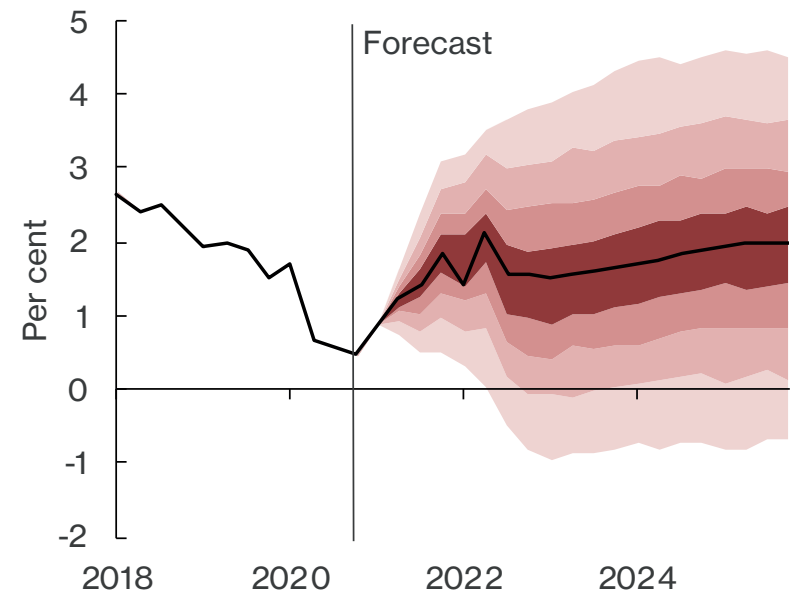

Note: The fan chart is intended to represent the uncertainty around the main-case forecast scenario shown by the black line. There is a 10 per cent chance that CPI inflation in any particular year will lie within any given shaded area in the chart. There is a 20 per cent chance that CPI inflation will lie outside the shaded area of the fan. The Bank of England's CPI inflation target is 2 per cent per annum.

Source: NIESR forecast and judgement. 
and stay close to 5 per cent for a prolonged period if the Monetary Policy Committee delays its response due to concerns about higher unemployment and higher public and private debt post-pandemic.

Expectations for RPI inflation implied by forward interest rates for the coming years do not yet show a sign of material increase even though they were higher in March 2021 than in February 2020 (see Figure 1.25).

No rise in Bank Rate is forecast for over two years though its relationship with the unwinding of $Q E$ remains uncertain

Policy interest rates have been maintained at 0.1 per cent and remain at that level in our main case forecast scenario until the second half of 2023 in line with the Bank of England's communication that the Monetary Policy Committee does not intend to tighten monetary policy at least until there is evidence that the 2 per cent inflation target can be sustainably met. The Bank of England is currently reviewing its policy of continuing to roll over maturing gilts until Bank Rate is at least 1.5 per cent.

Payment of interest on reserves may come under review if Bank Rate rises ahead of schedule

Given the higher share of government debt held by the Bank of England and increased sensitivity of government interest costs to the Bank Rate (see Box B on interest rate sensitivity of debt), there is uncertainty regarding which instrument will move first when the Bank decides to tighten its policy stance. In the Institute's recent publication on the subject Holtham (2021) suggests alternative ways to conduct reserves policy when the Bank starts raising interest rates.

The Bank of England has also been consulting on the introduction of negative interest rates to widen its policy
Figure 1.25 UK instantaneous implied inflation forward curve

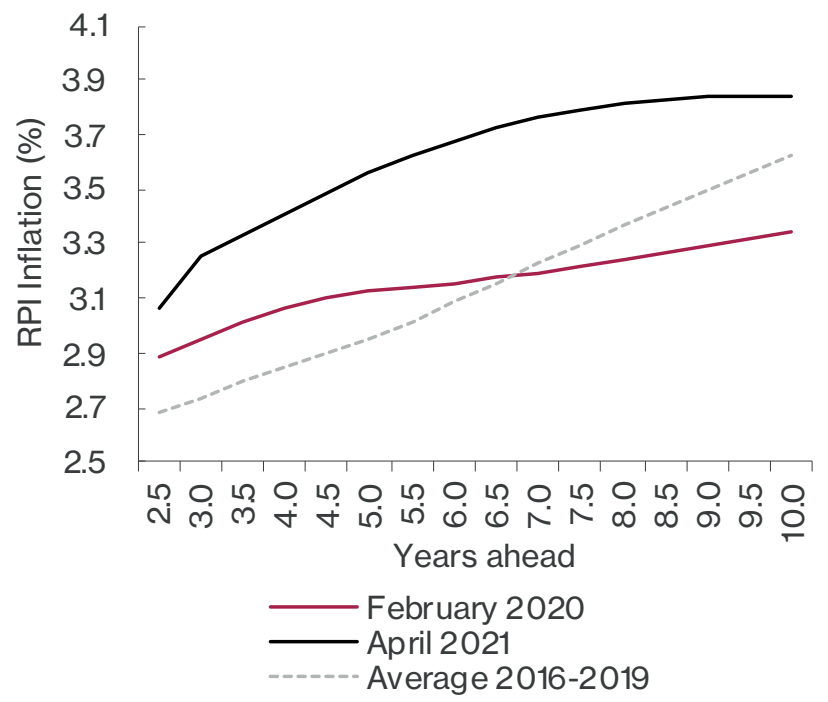

Note: RPI inflation rates derived from the gilt yield curve include an inflation risk premium related to liquidity. They also be affected by Asset Purchase Facilities expansion, involving the purchase of non-index-linked gilts.

Source: Bank of England and NIESR calculations.

toolkit to deliver further easing in monetary policy stance if required: see Section 2.3 of Barwell et al, 2020). As the uncertainty about both the direction and instruments of monetary policy continues, asset prices and financial conditions adjust to market participants' expectations which may not necessarily reflect Bank of England's intended policy stance going forward, as discussed in Box C). 


\section{Box C MPC communication: the case for taking back control of financial conditions}

Richard Barwell ${ }^{19}$

Expectations about the decisions that central banks will take in the future matter. Any change in the level of the short-term policy rate or the stock of asset purchases will have a negligible impact on asset prices and ultimately inflation if investors expect that change to be soon reversed. Central bankers have become more comfortable talking about the future path of policy in order to anchor those expectations. Nonetheless, the current conversation about the future path of policy in the United Kingdom still falls a long way short of 'complete forward guidance' (Barwell and Chadha, 2013).

Complete forward guidance involves disclosure of all relevant aspects of the internal policy debate, simultaneously reducing uncertainty within financial markets and the accountability deficit with politicians and the general public (Giles (2019)), and includes the following seven key elements:

1 Publish 'optimal' modal paths for each of the policy instruments - that is, paths that are considered the most likely to deliver the best possible economic outcomes (according to central bank's mandate) given the central bank's (inevitably) uncertain understanding of the current state and structure of the economy;

2 Place those modal policy paths within probabilistic statements (such as a fan chart) that illustrate the range of possible outcomes for the policy instruments and are internally consistent with the probabilistic statements about macroeconomic variables that central banks currently publish;

3 Release a detailed exposition of the strategy debate that highlights key points of uncertainty and critical judgements and their quantitative importance on the policy decision, and then illustrates that uncertainty by describing the alternative scenarios that are discussed within the internal policy debate (including the corresponding shifts in the policy path);

4 At moments such as these, when the policy setting is far from "normal", publish an exit strategy that describes how the central bank expects to return the policy instruments to normal settings, including details on the pace and sequencing of exit and how that might depend on economic and perhaps calendar considerations, as well as estimates of what constitutes "normal" for the policy rate and the balance sheet;

5 Provide a regular quantitative update on the policy committee's evolving understanding of the structure of the economy - again, with an emphasis on probabilistic statements not point estimates - and with a particular focus on timeless issues in the strategy debate, such as the slope of the short-run Phillips Curve, the transmission mechanism of policy instruments and the location of constraints on those instruments;

6 Produce a detailed description of the loss function that ultimately guides the entire policy debate which can then be used to evaluate alternative policy paths in a given circumstance and explain how the 'optimal' path was selected.

7 Wherever disagreements exist within policy committees, those differences should be disclosed - for example, each committee member should publish his or her understanding of the optimal paths, consistent with his or her beliefs about the state and structure of the economy.

There is no disputing the claim that the Bank of England's current communication strategy falls short of this limiting case. The extent to which that matters depends on the uncertainty of the audience. If the audience is well informed and already knows what the Bank would say if it were to deliver complete forward guidance then the message would be redundant. Those circumstances might be a reasonable approximation to reality at certain points in a typical business cycle. Unfortunately, it is almost certainly not the case now. The direction of travel is particularly unclear - whether the next move in policy will be to tighten or loosen - and more unusually still, it is unclear how the Bank of England would tighten or loosen.

If the width of the MPC's inflation fan chart is anything to go by then there is always massive uncertainty about the future path of rates given the likely size of the interest rate multiplier. According to the Bank's own forecasting platform, a surprise 25 basis point increase in interest rates knocks around 10 basis points off inflation (Burgess et. al., 2013). If there is a roughly one in three chance of inflation being 100 basis points or move above or below

19 BNP Paribas Asset Management and NIESR Fellow. The author would like to thank Jagiit Chadha for helpful comments. 
the target two to three years from now as the fan charts imply then there is a distinct possibility that a very large correction in the policy stance might soon be warranted in either direction.

It seems reasonable to conclude that the uncertainty over the macro outlook is particularly elevated at this juncture as the economy unlocks after a year of social distancing restrictions. Indeed, there seems to be considerable disagreement within the Committee, particularly with regards to the medium-term trajectory of inflation. The external members have argued that: "we should not forget that disinflationary pressures predated Covid" (Tenreyro, 2021); it will probably "take longer to close the output gap than forecast in the February MPR" (Saunders, 2021)); and there is "relatively little risk of sustained above-target inflation" as demand recovers in 2022 (Haskel, 2021 ). Meanwhile, the Chief Economist has argued that "there is a tangible risk that inflation proves more difficult to tame, requiring monetary policymakers to act more assertively than is currently priced into financial markets" (Haldane, 2021). But as is almost always the case, that material dispersion of views is not reflected in a material dispersion of votes (Barwell, 2016 and 2019): all of these people voted for exactly the same stance in March.

There does not appear to be a consensus within the Committee on the marginal tool for easing the monetary stance. There is a consensus that QE is the answer in the event of stress in core wholesale financial markets. However, it is debatable whether emergency interventions of that kind should be considered conventional monetary operations and in any case, it would be surprising (and concerning) to learn that MPC members perceived that the probability of this stress arising was sufficiently high such that more QE was "the marginal tool" for this reason.

There does not appear to be a consensus that more QE is the answer when inflation is expected to under-shoot the target in the medium-term. Vlieghe (2021) observes that "when long term yields are already very low (close to the effective lower bound on the policy rate (ELB)) and there is ample liquidity in markets, there is little QE can do to add further stimulus to the economy". Indeed, there does not appear to be a consensus within the Committee about how QE works, even if there tends to be a consensus within the Committee on how much QE to do (Barwell, 2020). This is an example of where the Bank could benefit from a more sophisticated communication strategy, which links theory and evidence on QE to views and votes on the Committee (BoE IEO, 2020).

There also appears to be a disagreement over the obvious alternative to more QE: negative rates. The external members appear to see some merit in cutting below zero and Tenreyro and Vlieghe have helpfully provided some quantification on how far: both have suggested that Bank Rate could be cut to as low as -0.75 per cent. How low Bank Rate can ultimately go - or perhaps more precisely, how low for how long - will depend on the complimentary measures that the authorities are willing to take to mitigate the side effects, including some radical measures (see Grady (2019) for a detailed exposition) but it is unclear how far Bank thinking has progressed on these issues. Indeed, several members of the Committee were willing to delay the contingency planning that was announced in February and thereby forgo the option of being able to cut into negative territory in August just to avoid any risk of sending a signal that the MPC intended to cut below zero. Revealed preference suggests that those individuals may need a lot of persuading to vote for negative rates.

The debate over the marginal tool to tighten policy was settled under Governor Carney: raise Bank Rate until there is once again scope to materially cut rates and then, and only then, begin to reduce the balance sheet. However, this Governor has expressed the view that "it may be better to consider adjusting the level of reserves first without waiting to raise interest rates on a sustained basis" (Bailey (2020)). The February policy statement confirmed that the exit strategy is now officially under review although it is unclear whether this refers to the threshold for Bank Rate at which balance sheet run-off can begin or the entire sequencing of rate hikes and run-off.

In short, the interaction between the unprecedented macro back-drop and the Bank's communication strategy has resulted in considerable uncertainty about both the direction and instruments of policy. Indeed, there is a sense that as the toolkit expands, guidance retreats with the Governor insisting: "We have been quite clear these toolkit decisions should not be interpreted as a signal about the future path of monetary policy" (Bailey, 2021). Meanwhile, expectations about the future path of policy implicit in market prices have shifted: the expected path of Bank Rate has moved higher and other asset prices - notably the currency - have moved in sympathy.

There is no debate over whether that this adjustment in the expected rate path and the concomitant correction in financial conditions matters or not, irrespective of whether the Committee believes it is warranted or not. It is the expectations of market participants embedded in asset prices that drive activity and ultimately inflation, not the counterfactual constellation of asset prices that is consistent with the beliefs in policymakers' heads. Failure to communicate clearly in an environment of pervasive uncertainty delegates partial control of the monetary stance 
to the collective beliefs of market participants. Those beliefs may not be anchored on reality. If the MPC will not talk then it will have to act - changing policy to change market prices - or face the consequences for activity and inflation. Concrete progress towards complete forward guidance seems a wiser course of action.

\section{REFERENCES}

Bailey, A (2020), ‘Central bank reserves can’t be taken for granted', Bloomberg.

Bailey, A (2021), 'Getting over Covid', Speech.

Bank of England Independent Evaluation Office (2020), Evaluation of the Bank of England's approach to quantitative easing.

Barwell, R. (2016), 'Nine votes, one view and the never-ending consensus on the MPC during the great stability', in J. Chadha, A. Chrystal, J. Pearlman, P. Smith and S. Wright (eds), The UK Economy in the Long Expansion and its Aftermath, Cambridge.

Barwell, R (2019), 'Inertial Groupvote: Reforming the decision-making process', in R. Barwell and J. Chadha (eds.) Renewing our Monetary Vows, NIESR.

Barwell, R (2020), 'Bank of England should switch strategy on QE, Financial Times, 9 December.

Barwell, R, and Chadha, JS (2013), Complete forward guidance, in W. den Haan (ed.), Forward Guidance, CEPR.

Burgess, S., Fernandez-Corugedo, E., Groth, C., Harrison, R., Monti, F., Theodoridis, K. and Waldron, M. (2013), The Bank of England's forecasting platform, Bank of England Working Paper 471.

Giles, C (2019), 'The oversight and accountability of monetary policy', in R. Barwell and J. Chadha (eds.) Renewing our Monetary Vows, NIESR.

Grady, M (2019), 'Can the effective lower bound be reduced? The case for negative policy rates', in R. Barwell and J. Chadha (eds.) Renewing our Monetary Vows, NIESR.

Haldane, A. (2021), 'Inflation: a tiger by the tail?', Speech.

Haskel, J. (2021), 'Remarks on challenges to the economic outlook', Speech.

Saunders, M. (2021), 'Supply and demand during and after the pandemic', Speech.

Tenreyro, S. (2021), 'Remarks on challenges to the economic outlook', Speech.

Vlieghe, G. (2021), 'An update on the economic outlook', Speech.

\section{REFERENCES}

Armantier, O., Goldman, L., Koşar, G., Lu, J., Pomerantz, R. and van de Klaaw, W. (2020) 'How have households used their stimulus payments and how would they spend the next?', Liberty Street Economics blog, New York Federal Reserve, October 2020

Bank of England (2021a) 'How has Covid affected firms' costs and prices?', Bank Overground, April 2021

Bank of England (2021b) Monetary Policy Report, February

Barwell, R., Chadha, J. and Grady, M. (2020) Monetary Policy in Troubled Times, NIESR Occasional Paper No. 59

Borchert, I and Morita-Jaeger, M. (2021), 'Taking Stock of the UK-EU Trade and Cooperation Agreement: Trade in Services and Digital Trade', UKTPO Briefing Paper 53 January 2021

Born, B., Müller, G.J., Schularick, M. and Sedláček, P. (2019) 'The Costs of Economic Nationalism: Evidence from the Brexit Experiment', The Economic Journal 129 (623), October 2019, pages 2722-2744

Chadha, J. (2017) 'Commentary: The Economic Landscape of the UK', National Institute Economic Review 240, May 2017

Chadha, J., Küçük, H. and Pabst, A. (eds.) (2021) Designing a New Fiscal Framework: Understanding and Confronting Uncertainty, NIESR Occasional Paper No. 61
Crafts, N. (2019) 'Persistent Productivity Failure in the UK: Is the EU Really to Blame?', National Institute Economic Review 247, February 2019

Ebell, M. (2017) 'Will New Trade Deals Soften the Blow of Hard Brexit?', NIESR blog, January 2017

Fuentes, N.M. and Moder, I. (2020) 'The scarring effects of past crises on the global economy', ECB Economic Bulletin $8 / 2020$

Hantzsche, A. and Young, G. (2019), 'The Economic Impact of Prime Minister Johnson's New Brexit Deal', National Institute Economic Review 250, November 2019.

Holtham, G (2021) Monetary Policy and the Value of Public Debt in J. Chadha, H. Küçük, A. Pabst (eds) Designing a New Fiscal Framework: Understanding and Confronting Uncertainty (pp. 71-86), NIESR Occasional Paper No. 61.

Hughson, H. (2021) 'What are the implications of Covid-19 for wealth inequality?', Economomics Observatory, 17 March 2021

Idriss, O. and Rocks, S. (2020) 'Did hospital capacity affect mortality during the pandemic's first wave?', Health Foundation, November 2020

Ilzetzki, E. (2021) 'Post-Covid-19 potential output in the euro area', VoxEU, January 2021

Kaplan, G., Violante, G.L. and Weidman, J. (2014) 'The wealth hand-to-mouth', NBER Working Paper 20073 
Knotek, E.S., McMain M., Schoenle, R., Dietrich, A.M., Myrseth, K.O.R. and Weber, M. (2021) 'Expected PostPandemic Consumption and Scarred Expectations from COVID-19', FRB Cleveland Economic Commentary 202111, April

Macqueen, R. (2020a), "Box B. Upside and downside risks to inflation", Prospects for the UK Economy, National Institute Economic Review, No. 253, August 2020.

Macqueen, R. (2020b) 'Labour market policies and productivity', National Institute Economic Review 254, November 2020

Malmendier, U. and Shen, L.S. (2019) 'Scarred Consumption', Federal Reserve System International Finance Discussion Papers 1259

Office for National Statistics (2021) 'Productivity economic commentary, UK: October to December 2020', 14 April 2021.
Pissarides, C. (2020) 'As COVID-19 accelerates automation, how do we stop the drift into long-term unemployment?', LSE Blog, 21 July

Smith, J. (2021) 'Macroeconomic Policy Outlook Q1 2021', Resolution Foundation, April 2021

Tenreyro, S. (2020) "Monetary policy during pandemics: inflation before, during and after Covid-19", Speech, Bank of England, April 2020

McKinsey (2021) 'Will productivity and growth return after the COVID-19 crisis?', Special Report, McKİnsey Global Institute, March 30, 2021.

Van Ark, B. (2021) 'Statement following the Q4-2020 Flash Estimates of Productivity for the UK', The Productivity Institute, February 23, 2021. 